University of Louisville

ThinkIR: The University of Louisville's Institutional Repository

Electronic Theses and Dissertations

$5-2012$

\title{
The budget gap : gender discrimination in the U.S. federal budget process, 1962-2011.
}

Kevin Fahey

University of Louisville

Follow this and additional works at: https://ir.library.louisville.edu/etd

\section{Recommended Citation}

Fahey, Kevin, "The budget gap : gender discrimination in the U.S. federal budget process, 1962-2011."

(2012). Electronic Theses and Dissertations. Paper 417.

https://doi.org/10.18297/etd/417

This Master's Thesis is brought to you for free and open access by ThinkIR: The University of Louisville's Institutional Repository. It has been accepted for inclusion in Electronic Theses and Dissertations by an authorized administrator of ThinkIR: The University of Louisville's Institutional Repository. This title appears here courtesy of the author, who has retained all other copyrights. For more information, please contact thinkir@louisville.edu. 
THE BUDGET GAP: GENDER DISCRIMINATION IN THE U.S. FEDERAL BUDGET PROCESS, 1962-2011

\author{
By Kevin Fahey \\ B.A., Ohio Wesleyan University, 2006 \\ Master of Arts \\ Department of Political Science \\ University of Louisville \\ Louisville, $\mathrm{KY}$
}

\begin{abstract}
A Thesis
Submitted to the Faculty of the

College of Arts and Sciences of the University of Louisville in Partial Fulfillment of the Requirements

for the Degree of
\end{abstract}

May 2012 
THE BUDGET GAP: GENDER DISCRIMINATION IN THE U.S. FEDERAL BUDGET PROCESS, 1962-2011

\author{
By Kevin Fahey \\ B.A., Ohio Wesleyan University, 2006
}

A Thesis Approved on

April 19, 2012

By The Following Thesis Committee

\author{
Laurie Rhodebeck, Thesis Director
}

Anne Caldwell

Karen Christopher 


\section{DEDICATION}

To Kelsie, for being herself 


\section{ACKNOWLEDGEMENTS}

This paper would not have been possible were it not for the encouragement and sage counsel of Dr. Laurie Rhodebeck, my thesis director. I would also like to thank Dr. Anne Caldwell for her influential wisdom and support. Dr. Karen Christopher deserves praise for providing crucial help and assistance. Owen Graham deserves credit for providing the inspiration for this paper. Finally, no idea is born in a vacuum and no person achieves accomplishment without the support and strength of an entire community. The faculty, staff, and graduate students of Ford Hall have given this paper more than its author could ever hope to return, and for that I am eternally grateful. 


\begin{abstract}
THE BUDGET GAP: GENDER DISCRIMINATION IN THE U.S. FEDERAL BUDGET PROCESS, 1962-2011

Kevin Fahey
\end{abstract}

April 19, 2012

The persistent private sector wage gap between men and women is one of the more intractable deficiencies of modern American society. It may be symptomatic of male privilege, a theory that outlines pervasive, ubiquitous discrimination that favors men from birth until death. However, egalitarian wage laws passed by Congress rigidly enforce equal pay for equal work at the highest echelons of public service, including Congress, the Cabinet, and the presidency. Is male privilege likely to manifest despite such legislation? If we assume that members of the Cabinet are lobbyists or representatives of their agencies, with Congress as the constituent, pervasive discrimination against women might result in reduced budgetary capacity for female-run Cabinet agencies. This project examines the budgetary outlays data of the US Cabinet from 1962-2011 to examine whether or not the sex of secretaries in the Cabinet influence the size of their department's budget. The results show that there is a relationship between gender and budget size, but other characteristics of Cabinet secretaries are more influential, such as marital status, career choice, and level of education. 
TABLE OF CONTENTS

\section{DEDICATION}

\section{ACKNOWLEDGEMENTS}

ABSTRACT

LIST OF TABLES

CHAPTER ONE: INTRODUCTION..............................................1

The Budget Gap..............................................................

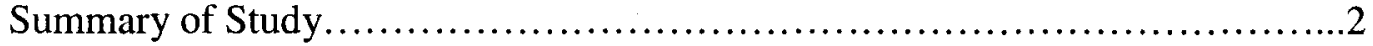

CHAPTER TWO: LITERATURE REVIEW $\ldots \ldots \ldots \ldots \ldots \ldots \ldots \ldots \ldots \ldots \ldots \ldots \ldots \ldots \ldots . . \ldots \ldots$

The US Cabinet............................................................. 5

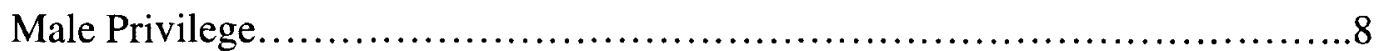

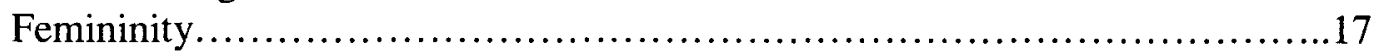

The Federal Budget Process................................................24

Summary of Key Theoretical Concepts....................................28

CHAPTER THREE: DATA, METHODS, AND HYPOTHESES....................31

Data Collection........................................................ 31

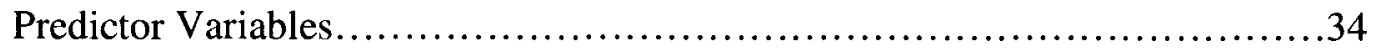

Methodology.............................................................. 41

Hypotheses.........................................................45

CHAPTER FOUR: FINDINGS.......................................................46

Bivariate Discussion....................................................46

Multivariate Regression Discussion.......................................48

Discussion of Time Counters............................................. 51

Confirming, Counterintuitive, and Contingent Results........................54

CHAPTER FIVE: CONCLUSIONS...........................................60

TABLES AND FIGURES............................................................68

REFERENCES................................................................75

CURRICULUM VITA..............................................................80 


\section{LIST OF TABLES}

Table 1 - Personal Characteristics of Cabinet Secretaries by Sex, 1962-2011.............68

Table 2 - Display of Cabinets by Cabinet-Year Characteristics 1962-2011..............68

Table 3 - Percentage of Cabinet Secretaries with Personal Characteristics by Administration, 1962-2011.................................................69

Table 4 - Bivariate Correlations between Predictor Variables and Dependent Variables (Sex of the Secretary and Budget Outlays).............................................69

Table 5 - Showing the Effects of Personal Characteristics on Budget Expenditures,

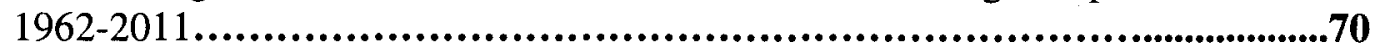

Table 6 - Effects of Predictor Variables on Budgetary Expenditures with the Insertion of a Dummy-Variable Time Counter................................................71

Table 7 - Effect of Predictor Variables on Budgetary Expenditures when an interval Time Counter is Inserted........................................................72

Table 8 - Measures of Sex for All Variants of the Multivariate Model.....................72 


\section{LIST OF FIGURES}

Figure 1 - Gender by Law Degree...............................................73

Figure 2 - Gender by Party of the President............................................73

Figure 3 - Gender by Democratic Control of Congress................................74

Figure 4 - Gender by Marital Status (Divorced)..........................................74 


\section{CHAPTER ONE INTRODUCTION}

\section{The Budget Gap}

It is an accepted fact of life that American society is dissimilar for women and men. The most universally recognized quantification of this gendered inequality is the private-sector salary gap that shows women receive roughly 80 cents for every dollar men earn in wage compensation (Renzulli et al 2006; Gose 2004). Many scholars attribute this discrepancy to the idea of 'male privilege', a pervasive force in society wherein men are systematically the beneficiaries of rules and norms. Yet in the public sector, laws require that government employees must earn equal pay for equal work, regardless of sex. Given that male privilege is an unconscious social force rather than the deliberate actions of rational human beings, it seems unlikely that these laws will undo generations of gendered inequality. This paper hypothesizes that male privilege will find its way around legislation and enforce male-centric norms and perks in other ways.

At the federal level, male privilege could manifest itself through the annual budget process. If this were the case, Congress and the presidency would reduce the growth of, or cut in absolute terms the federal budgets of Cabinet departments run by female public servants. Cabinet departments or administrations that have above-average numbers of female secretaries would likewise be subject to discrimination. The publicservice positions most likely to be affected by the clash of egalitarian legislation and traditional gender norms would be Congress and the Cabinet, both of which are 
comprised of both men and women. However, the Cabinet is a more useful tool for study because the fifteen men and women who make up the secretaries of the Cabinet are seen as lobbyists for their agencies (Borrelli 2002; Warshaw 1996), whereas Congress' interests are much more fragmented by a larger scope of activities. The gender of Cabinet secretaries would thus be far more crucial in determining whether or not male privilege impacts the federal budget process. This study examines sex in the federal Cabinet from 1962-2011 and compares it to federal budgetary outlays to determine if female secretaries are the victims of discrimination.

The method by which I expect male privilege to influence departmental budgets is through the prism of a constituent-representative relationship wherein the constituency of Congress examines the attributes of their representatives in the Cabinet and then uses that assessment to judge the competence of the representative. In this model, personal traits such as gender and family composition are as influential as professional characteristics such as education level or partisanship. In essence, the competence of secretaries of the Cabinet may be determined by their sex. If male privilege were apparent, this type of attribute assessment would be systematic and adversely affect female Cabinet members.

\section{Summary of Study}

This study is very timely; until the presidency of Bill Clinton, there had never been more than a few women in the US Cabinet at any given time. Along with successor Presidents George W. Bush and Barack Obama, Clinton ushered in a period of a relatively female-friendly Cabinet. The proliferation of women to the Cabinet has made quantitative analysis of gender in the Cabinet feasible. Given the trends of the past 
twenty years, it is likely that future presidents will only add to the proportion of women in the Cabinet. At the same time, this will add to current literature on the US budget process by identifying variables designed to predict the outcome of the annual federal budget.

Prior literature focuses on one of the three topics: the budget process, women in public service, and the relationships between the major governing institutions at the federal level. This paper hopes to combine these studies into a comprehensive literature review as a backdrop to analysis. In doing so, it will produce a picture of a federal government and budget that is affected by the gender of its public servants. I hypothesize that there is a negative relationship between budgetary outlays and whether a secretary on the Cabinet is female.

The data collected came from a wide variety of sources rather than a small number of existing data sets and as such may offer a unique perspective on how political scientists examine the budget process and gender in the US Cabinet. That said, significant portions of this dataset were collected from the US Government Printing Office, the Center for American Women in Politics, and The United States Executive Branch (Sobel and Sicilia, eds. 2003) and the information relayed by those sources was invaluable to the production of this study. Data collected included: personal characteristics and professional attributes of every Cabinet secretary from 1962-2011; budgetary outlays and other fiscal data for that same time period; measures of partisanship, gendered demographics, and confirmation voting behavior of Congress and the presidency from 1962-2011; and House Appropriations Committee votes on the budget from 1986-2011, the only available data for those votes through the US House 
Office of the Historian. After collection of all pertinent data, bivariate and multivariate analyses were run, resulting in a series of twelve ordinary-least squares regression variants on the core model. As this study examines a large period of time, two time counters were employed to test differing assumptions about the nature of evolving gender norms in American society as well as growing partisanship in Washington.

The results of this analysis are broken down into three subsections: confirming, counterintuitive, and contingent results. The variables most central to the study, those of sex and partisanship, are statistically significant and show clear directionality contingent upon various measures of time included in or excluded from the model. The measure of sex by individual, the core of this study, is significant and negatively associated with budgetary outlays only for the time period 1986-2011 and when a dummy time counter from 1992-2011 is included in the model. The implications of these results, and the possible avenues for new research on gender in the federal bureaucracy, are discussed at length in the final chapter. 


\section{CHAPTER TWO \\ LITERATURE REVIEW}

The following theoretical constructs will be used to create a vision of a federal budget process through which gender and sex influence the real budgetary outcomes of the primary actors in the federal bureaucracy, the top echelons of each Cabinet department. The literature will explain the role of the Cabinet in the budget process, followed by the ways gender impacts the Cabinet and the other major actors of that process. Finally, it will look at the budget process itself. When complete, it will demonstrate that these institutions operate together to promote a system of male privilege against which female officeholders encounter substantial disadvantages.

\section{The US Cabinet}

The Cabinet of the President of the United States of America was a philosophical outgrowth of advisers to the King of England, and the colonists adapted it to use for the Articles of Confederation. During the Constitutional Convention of 1787 , the delegates debated the role of the Cabinet in presidential policymaking, with the prevailing opinion being that the executive would require the presence of additional minds in order to introduce diversity and reduce some of the unilateral power of the president himself (Warshaw 1996). Four departments were created that now constitute the Inner Cabinet (Borrelli 2002; Dolan 2001; Borrelli and Martin 1997): War, State, Treasury, and the Attorney General (Warshaw 1996). The Cabinet has since grown by eleven new 
departments; the most recent addition occurred in 2005 with the establishment of the Department of Homeland Security.

In addition to growth in size, the Cabinet has developed a significant amount of autonomy over the past century, to the point where it makes sense to refer to the Cabinet as separate from the presidency. In the 1800 s, the Cabinet acted as policy advisers to the president, and individual Cabinet members such as Daniel Webster, Edwin Stanton, and even William Jennings Bryan held considerable political power (Warshaw 1996). However, in many cases the president distrusted some of his secretaries and had small kitchen Cabinets upon which to rely. The administration of Franklin Roosevelt began the practice of employing professionals in the White House staff to act as policy advisers (Warshaw 1996). By the administration of Ronald Reagan this staff had swelled to hundreds and the Cabinet had become relegated to the status of administrators of their own departments (Warshaw 1996). As such, currently secretaries come into office with little connection to the policy goals of the president but with the aim of maximizing the gains of their own agencies ${ }^{1}$ (Rubin 1993).

How the Cabinet works today is much more complicated than the vision of advisers to the president set up by the Founders. Each Cabinet secretary submits his or her budget proposal, detailing the expenditures thought necessary to sustain current or expected services, to the president who then packages the requests into a budget submitted to Congress (Rubin 1993). Over the course of the year, the Cabinet then acts as an administrator of the appropriated budgetary authority, going to Congress to secure

\footnotetext{
${ }^{1}$ Some feminists see the goal of bureaucracy as a mechanism for societal control rather than providing government services to constituents. This radical interpretation is not used in this paper but may be a valid tool for analyzing potential gendering of the annual budget process. See Kathy Ferguson, The Feminist Case Against Bureaucracy (1984).
} 
funds as they are doled out, and managing the myriad offices of their department (Benjamin 2001; Rubin 1993; Martin 1991). Increasingly, duties for these individuals include publicity or campaign events for the administration (White House Press Release), hearings before Congress, or - in the case of certain departments like the Judiciary or the Secretary of State - more specialized events including diplomatic travel and high-level federal cases (State.gov 2011; Justice.gov 2011). Each Cabinet member is expected to be not just a competent administrator but a political figure in his or her own right.

The Cabinet's relationship with Congress in this vein is much like a model of candidates running for Congress relating to their constituents, or other agent-client relationships in the federal government (Szmer et al 2010). Like a candidate, a Cabinet secretary is interested in currying good favor with his or her constituencies in order to receive the rewards of political office (Shomer 2009; Fox and Oxley 2003), election to office for the candidate, and maximized budget authority for the bureaucrat. Much like voters, Congress is a diverse constituency with mixed political, ideological, and personal ambitions that the Cabinet must navigate in order to achieve success (Levine 2005; Hogan 2001; King and Riddlesberger 1991). However, unlike an electorate-candidate model, the Cabinet and Congress must learn to live with each other for up to eight years even if they dislike each other; a strong relationship between a secretary and relevant congressional committees must be cultivated regardless of partisan, ideological, or personal differences. These differences are often exacerbated by the presence of personal components, such as gender, that have a strong history of arousing prejudice and bias.

The presence of women in the Cabinet is a relatively new phenomenon; before the Nixon administration there were only two women ever appointed to serve. Since then, 
the number of women has risen considerably; in 1992 the number of women in the US Cabinet has exceeded 20\% and has averaged above 25\% in Bill Clinton's (Grey 2006; Borrelli and Martin 1997) and Barack Obama's administrations. Moreover, there have been female secretaries in' all but three US Cabinets, providing plenty of opportunity to study any gender-related phenomena in the budget process (Borie-Holtz 2011; Borrelli and Martin 1997).

\section{Male Privilege}

The institution of the Cabinet acts in conjunction with the presidency and Congress to pass formal budget policy and fund government programs and services. If gender is considered, discrimination against female public servants may be explained in part by pro-male bias in these institutions. ${ }^{2}$ The relevant parts of the presidency are largely an all-male cast; the president has always been a man and only Alice Rivlin from 1994-1996 has been a female OMB Director. The number of women in the federal government has increased substantially since 1962 (Davis et al 1993) but still number fewer than 20\% of the members of Congress (McDonagh 2010; Grey 2006) and only slightly more in the bureaucracy. Some scholars believe that this critical mass of women in the Cabinet will change how gender in the Cabinet is perceived; scholars disagree over what percentage of women are required to change gender norms in an institution (Grey 2006). More women traditionally occupy the lower echelons of government service, so the number of women at the top of the federal bureaucracy suggests that the bureaucracy

\footnotetext{
${ }^{2}$ This paper acknowledges the growing literature on intersectionality, specifically that gender, class, and race all work in American politics to discriminate against those who are not white, male, and middle-class or wealthier. For the purposes of this paper, I will simplify by ignoring class and race. Class is not a large discriminatory factor in the USi Cabinet since the ranks of candidates for the Cabinet are overwhelmingly upper-class.
} 
may be reaching a critical mass capable of affecting gender perceptions or may simply be an avenue for competent female government employees who are often kept out of the most prestigious electoral government positions (Borie-Holtz 2011; Bowling 2006; Borrelli and Martin 1997; Ferguson 1984), although women are more prevalent in some 'women's issues' departments than others (Bowling 2006). At no point have the accumulated budgets of female Cabinet secretaries ever exceeded half of the federal budget (GPO 2012). Why is there such a strong bias against gender equality at the highest echelons of government service?

Male privilege is the key element in how gender could affect government makeup and budgetary expenditures. Literature that describes male privilege argues that society is set up to favor and advantage men over women (Howell 2000; hooks 2000; Rich 1993; Acker 1990). Privilege is a relative term; those within the sphere of the privileged or advantaged are members of "an influential status that engenders favor" (Parsons 2001: 322). Those outside the privileged circle cannot count on, take for granted, or receive the advantages of a system designed upon norms that the privileged rely upon as basic or fundamental (Ferber et al 2007; Parsons 2001). Outsiders are more often referred to as oppressed or victimized by this system of inequality (Ferber et al 2007; hooks 2000; Acker 1990).

In the American political system these forms of privilege no longer take shape in traditional ideas about gender roles; women have entered the workforce, the military, and many other spheres of society not previously occupied by women in substantive numbers. Most importantly, federal and state governments have set in place laws to prohibit gender inequality in their workforce, although the failure of the Equal Rights Amendment in the 
1970s is an exception. Today, male privilege manifests itself in more subtle mechanisms, even in subtle media messages (Kahn 1994). Women are permitted to join the military but may not participate in combat (hooks 2000); there are female secretaries but no female Secretary for Veterans' Affairs ${ }^{3}$ (Borrelli 2002). There have been two major party candidacies for women to become vice president and one major party attempt for a female president, but none of those efforts have succeeded. In many cases, women are reaching new levels of private and public employment but are kept out of powerful informal networks (Borie-Holtz 2011; Borrelli 2002; Dolan 2001; Borrelli and Martin 1997). Often, (largely male) party recruiters try to select women who are deemed successful enough to run for office and spurn those women who do not fit a particular mold (Sanbonmatsu 2002; Rule 1981). Institutions, including the federal bureaucracy itself, are not gender-neutral nor are they immune to the types of discrimination brought about by male privilege (Acker 1990; Ferguson 1984).

A competing phenomenon may be the growth of female privilege. While women in the US federal bureaucracy do not use their office to benefit female constituencies in a manner consistent with the activities of many legislative caucuses worldwide (Dolan 2002), there appear to be several distinct advantages to female candidacy for office. Many studies have noticed an electoral benefit that comes with being female, or the benefits that are found when the number of women in an institution increase (Fox and Lawless 2010). Head-to-head, women outperform male opponents in state legislative elections (Stambough and O'Regan 2007), and there is no significant fundraising gap between the sexes (Hogan 2001). Democrats are much more likely to nominate women to competitive elections to which the party diverts significant resources (Stambough and

\footnotetext{
${ }^{3}$ Since 1989, the Secretary for Veterans' Affairs has always been a former member of the armed forces.
} 
O'Regan 2007). While female privilege only appears to manifest sparsely and is not as acknowledged as male privilege, the emergence of this concept may be problematic for the idea of universal, pervasive gender bias.

For the two places with substantial numbers of female public servants (Congress and the Cabinet) examined in this study, male privilege will operate differently. In Congress, we would expect the proportion of women in budget-influencing committees to be under-represented compared to women in the larger Congress (Borie-Holtz 2011). We would also expect fewer women to head committees or party caucuses than are represented in the overall Congress. In the Cabinet, however, how would male privilege manifest itself? Like Congress, every member of the Cabinet is paid the same; unlike Congress, there are no formal institutions (such as committees or party leadership posts) for advancement. I hypothesize that Cabinet secretaries are judged primarily through their ability to maximize budget gains, and thus male privilege will restrict the growth of the budgets of female secretaries relative to male secretaries.

While women in the federal bureaucracy may over-perform in comparison to the proportion of women in the rest of the presidency or in Congress, these women may not get placed in the most powerful positions or may not be taken as seriously by colleagues. The professional qualities of secretaries to the Cabinet must also be taken into account, as their performance as professionals will undoubtedly be noticed by the other primary budget actors such as congressional budget committees, Congress at large, and the president's policymaking staff. Often, women are nominated to the Cabinet to serve as descriptive representatives rather than substantive representatives; these women are expected to serve as liaisons to particular constituencies rather than serve the 
administration as competent policymakers (Escobar-Lemmon and Taylor-Robinson 2009; Wilkins 2007; Borrelli 2002; Dolan 2001; Warshaw 1996). Such descriptive representatives often have a stigma attached suggesting they have not got the qualifications of their peers (Borrelli 2002; Borrelli and Martin 1997). As an example, in the Reagan administration, most women appointed to the Cabinet came from the District of Columbia region in contrast with men, of whom slightly less than half came from the greater District of Columbia metro region (Martin 1991). This would indicate that women in the Cabinet for this administration were not drawn from the best the country had to offer, but from personal networks; women recruited for Cabinet service in this manner are quite possibly policy generalists or descriptive representatives.

Descriptive representatives would on average be perceived by Congress and the presidency as policy generalists rather than policy specialists. I would expect these administrators to receive smaller budget increases due to their relative inexperience in the federal budget machinery. Women who enter fields beyond the stereotypical business or legal careers may also be harmed as candidates for the Cabinet (and later as secretaries in the Cabinet requesting budget increases) and these individuals may also be disadvantaged in the system (Borie-Holtz 2011). Rather than explicitly examining whether or not generalists or specialists are advantaged in the budget process, I argue that women in the Cabinet are discriminated against regardless of their background; a male generalist will be more favorably regarded than a female generalist, and a male specialist in any department will be more favorably regarded than a female specialist.

The professional qualities and backgrounds of women in the Cabinet may play a larger role than the professional qualities and backgrounds of men in any given 
appointment to the Cabinet (Jalalzai and Krook 2010; Fox and Lawless 2010; Dull and Patrick 2009; Fox and Lawless 2003; Howell 2000), especially when professional characteristics of the candidate for office are unknown (Alexander and Andersen 1993). This belief is based upon the growing gender gap in political perception of candidates as well as an issue gender gap (McDonagh 2010; Kellstedt et al 2010; Thomas et al 2008). Women in public office tend to be younger, have spouses also in powerful professions, and have had careers in 'feminine' professions at a higher rate than their male colleagues (Borie-Holtz 2011; Bobbitt-Zeher 2007; Borrelli 2002).

There is also a career process called the 'pipeline' that describes which candidates make their way through the echelons of government service (Stambough and O'Regan 2007). Several differences separate the pipeline for men and women. Women in Congress or state legislatures tend to come from legal and business careers - the two careers represented most in Congress - at a lower rate, coming instead from publicservice or community-service sectors of the economy (Mariani 2008). Female candidates for Congressional seats who have served in the state legislature are younger, and have a visible husband, fewer children, and more experience in the state legislature than women who do not advance from the legislature (Mariani 2008). Given that many Cabinet members are lifelong politicians, it is likely they move through this pipeline and are merely at a later stage of this process. As such I expect that many of these same traits will still apply and be as pertinent to their advancement through the budget process as they were to the success of their legislative careers. Descriptive information about members of the Cabinet until 2002 lends credence to this hypothesis; women in the 
Cabinet are often characterized by their spouse's connections to the government as much as their own and most have spent time in public elected office (Borrelli 2002).

Beyond the role of gendered inequality in the Cabinet, male privilege manifests itself through many customs and actors in the budget process beyond the qualities of the Cabinet, especially through the institutional powers of the presidency and Congress. The presidency has enormous power over the gender of its nominees given its role in nominating these persons to the Cabinet (Dull and Patrick 2009; Borrelli 2002). Given that the proportion of women in the Cabinet has never exceeded 30\%, it does suggest that the presidency may be a male-dominated institution operating under the presumption that the most powerful positions in the administration should be held by men (Borrelli and Martin 1997). Today's presidential budgetary officials streamline all Cabinet budget requests into the $\mathrm{OMB}$, where those requests are usually sent to Congress as a single package, rather than a series of smaller funding resolutions (Rubin 1993). Democrats have often provided a more successful pipeline to higher office than their Republican counterparts (Stambough et. al, 2007; Hogan 2001; Conover 1988) and may place women in positions directly tied to their agenda (Conover 1988). By contrast, the GOP has often placed women in token Cabinet positions such as Labor or HHS in order to try to receive some electoral benefits of diversity in the administration (Borrelli 2002). At the same time, Democrats have often voiced support for greater spending on programs and services from the federal government, in contrast to Republicans who employ small-government rhetoric in their campaigns.

Senate confirmation of a Cabinet secretary is very important to the relationship between that department and Congress, which oversees annual budget approval. Given 
that the secretary of the department is in many instances the public face of that department and often goes before Congress privately and publicly to lobby for funding (Warshaw 1996), a poor initial relationship between senators and secretaries could endanger a presidential agenda for an entire term. Congress sees itself as a gatekeeper for Supreme Court Justices, Cabinet officials, and other presidential appointments (Fox and Lawless 2010; Borrelli 2002). Senators are more likely to vote for officeholders when public opinion is in favor of that officeholder (Kastellac et. al, 2010). Confirmation votes have become more politicized in the past three decades, leading more senators to consider an actual floor vote rather than allowing a Cabinet official to take office via unanimous consent or a voice vote (King et. al 1991, Dull et. al, 2009). In many instances, discussion of the role and direction of public policy pertaining to that Cabinet's function becomes the epicenter of the confirmation process, rather than the qualifications of the nominee himself or herself (King et. al 1991). At times, the Senate sees women as women rather than as qualified officeholders (Borrelli 2002). The ideology of the senators may also play an important role when viewing gender; a study found that female litigants before the Supreme Court received fewer favorable votes, especially along ideological lines, than their male counterparts (Szmer et. al, 2010), suggesting that men will behave in a more hostile fashion to women of the opposite party (Borrelli 2002; Warshaw 1996). If we assume that the Supreme Court acts as a constituency to the litigant's representative, we can adopt a similar model for other intra-elite relationships. Thus any measure of the role of budget allocations for Cabinet departments must include a measure of the relationship between the Congress and the department in question. 
Beyond the crucial role of the Senate in confirming Cabinet members, the gender and partisanship of Congress may influence the makeup of a gendered budget process (Fox and Lawless 2010). Growth in the number of female members of Congress may make that institution more receptive to women in the Cabinet. Given that Cabinet members act as lobbyists on behalf of their agencies to Congress, a friendlier Congress will likely mean larger budgetary authority for those secretaries (Warshaw 1996); if male privilege exists Congress would automatically be less friendly to female secretaries than male secretaries, all other attributes considered. Rhetoric from the Republican Party over the past 50 years indicates that they prefer small-government policies, and their rhetoric and action on issues deemed important to women, such as abortion and contraception rights, suggest that Republican political elites are not as receptive to women as Democrats. Annual votes on the budget by Congress show the level of support of presidential and bureaucratic policies, acting as a mini-electorate (Grey 2006; Hogan 2001). A more thorough study of Congress' role in the budget process would examine the personal characteristics of each member of Congress (Mariani 2008), but for this study I assume that Congress acts as a constituent group that discriminates against those Cabinet secretaries who do not resemble the archetypal male, married, educated, and experienced secretary. Competence of any given secretary would be based upon personal attributes including sex; secretaries who deviate from superficial ${ }^{4}$ qualities such as being a woman would be seen as deviant from the archetype and less worthy of funding. Taken together, these structural factors play a role in keeping the current clout of female members of the Cabinet reduced relative to their male counterparts.

\footnotetext{
${ }^{4}$ In this paper, 'superficial' refers to all attributes of an agency that are not explicitly politically-oriented; this would include all characteristics of the secretaries.
} 


\section{Femininity}

Examining the bureaucracy as a gender-neutral apparatus through which we can experiment is a fallacy due to the structural gender inequities of American society (Acker 1990; Ferguson 1984). One of the major difficulties in researching gender in public life is demonstrated by feminist literature. Much feminist theory is either qualitative or normative, and in the latter tends to identify privileged language, empower marginalized groups, and advance "social justice [and] equality" (Apodaca 2009: 419). In some cases the goal of feminist theory is not to remove oneself and objectively analyze but to illustrate previously unquantified inequities in current societal paradigms and advocate for their elimination. This divide is not insurmountable; rather, feminist empiricists need to understand the distinction between positivism and normative feminist writings, and ought to create variables "that [are] a good operationalization of the concept [of gender]" defined by normative writers (Ackerly 2009: 433-434). The question of whether or not women can be classified as a 'group unto themselves' is itself controversial. Obviously, "women are by no means a coherent group and every female legislator will have crosscutting identity characteristics that [affect] her worldviews" (Grey 2006: 493). However, it is assumed here that female Cabinet secretaries are distinct enough from male Cabinet secretaries that the most feminine male secretary will still be perceived as 'a man' compared to the most masculine female secretary.

In this paper, institutional and professional backgrounds of the major actors in the budget process are accounted for and imply inherent structural disadvantages for women in the federal government. However, many studies have suggested that gender 
discrimination extends far beyond these de jure inequalities and into the realm of socialization, gender norms, and de facto gender segregation. At the heart of these studies is the idea that men and women possess different personality traits. These identity-forging qualities are usually defined as feminine or masculine by scholars, suggesting that certain personality attributes make a person less or more acceptable to men (Barakso 2007; Conover 1988). Male privilege would disadvantage those persons seen as feminine and give preference to those seen as masculine (Okimoto and Brescoll 2010). However, some literature finds the opposite: women are privileged by the electorate for possessing feminine gender traits by getting elected to office (McDonagh 2010; Hogan 2001). Perhaps by embracing stereotypical or traditional gender norms, female candidates become more appealing to voters (Huddy and Terkildsen 1993; Alexander and Andersen 1993). Some scholarship has also noted that female public servants who embrace stereotypical gender norms tend to embrace communal or unanimous decisions or policy (Davis et al 1993; Conover 1988). In an age of hyperpartisanship, it is possible that elected officeholders are interested in finding ways to bridge the gap, and may elevate female officeholders to special privilege in order to solve the country's political and economic problems.

In many studies on gender the cabinets as institutions are also broken down by masculine or feminine characteristics, which themselves may be amorphous, shifting traits (Escobar-Lemmon and Taylor-Robinson 2009; Borelli 2002; Huddy and Terkildsen 1993; Shapiro and Mahajan 1986). However, this does not translate into disproportionate spending directly for women by these feminine agencies (Dolan 2002). Elevating Kathleen Sebelius to the post of HHS Secretary in 2009 does not necessarily lead to 
increased opportunities for women within HHS itself, nor would HHS increase grants or loans to women's interest groups in such a case. Indeed, some scholarship has shown how easily these traits can be manipulated to make men or women appear more masculine or feminine (Huddy and Terkildsen 1993). Much of this literature examines narrow time frames, and given the rapidly evolving social position of women in America, many of these studies may be out of date (Sanbonmatsu 2002).

Naturally, this questions what constitutes a feminine trait versus a masculine trait. Deborah Alexander and Kristi Andersen attribute "honesty, compassion, and compromise as feminine whereas decisiveness, emotional stability, and ability to handle a crisis" as masculine (Alexander and Andersen 1993: 534). Finally, competence is regarded as a neutral trait - although the researchers simply 'assume' competence to be gender-neutral. Pamela Conover (1988) considers 'sensitivity, compassion, communal nature, and adaptability' as inherent to femininity. Other scholarship refers to an amorphous 'ethos of masculinity' or traditional gender/sex roles (Fox and Lawless 2010; Fox and Oxley 2003). This is not to say that research has not identified traits that are specifically designated to men or women, but that the same traits are not used uniformly nor is there a set of traits that is universally accepted. The electoral gender gap is noticed among whites but not any other ethnicities in the United States (Howell and Day 2000). A definition of gender stereotyping used in two studies reads as follows: "a division of activities into the public extra-familial jobs done by the male and the private intrafamilial ones performed by the female (Fox and Oxley 2003: 835)", and is echoed in other work (Conover 1998). This broad, generalist definition is capable of including

\footnotetext{
${ }^{5}$ The study goes on to say that "the conception of a rigid set of gender roles as an expected norm is certainly on the decline, the effects of traditional socialization continue to exist in the electoral arena generally" (Fox and Oxley 2003).
} 
whatever attributes a researcher prefers, meaning that cherry-picking of preferable data may occur, even unconsciously.

Further research produces conflicting opinions about how gender influences voters' selection of officeholders. Women who run for public office are just as successful in fundraising and electoral performance as men who run for office (Mariani 2008; Fox and Oxley 2003; Hogan 2001). This implies that discrimination against female public servants may not be wholly pervasive. Some literature suggests that women are analyzed for electability during the recruitment stage, and the women who survive that step conform to the gender norms of the time (Sanbonmatsu 2002; Rule 1981). However, the whole concept of male privilege in politics is that men are honored above women in every facet of life, so even when women conform to gender norms there are still measureable disadvantages (Jalalzai and Krook 2010; Kahn 1994; Acker 1990).

These feminine traits allegedly open a pathway wherein women are placed in agencies that reflect women's interests, such as agencies controlling income security, social services, education, health, economic development, regulatory agencies, or what Cynthia Bowling describes as 'other' (Bowling 2006). This list reads more like the summation of all programs excluding state Treasury, Commerce and Defense/National Guard departments, however, leading to suspicion that feminine or masculine attributes are assigned to departments, not the other way around. In the 1990s only naturalresources agencies had fewer than $10 \%$ of leadership posts nationwide run by women and the average number of female state Cabinet leaders across the country was 20\% (Bowling 2006). All agencies show an increase in the number of female department chiefs over the 
time period; perhaps showing which agencies grew the fastest in terms of female leadership could be an indicator of which agencies were more feminine.

This growth also runs counter to the argument of tokenism in the bureaucracy (Escobar-Lemmon and Taylor-Robinson 2009) and lends credence to the theory of critical mass (Grey 2006; Dolan 2002). Tokenism refers to the theory that certain minority groups are placed in certain institutions or parts of an institution that are stereotypically considered 'theirs' in order to fill racial, ethnic, or gendered quotas for a coalition party in power. By contrast, the theory of critical mass argues that institutions become gender-neutral or lose masculine dominance once the number of women in that institution reaches a certain proportion (Grey 2006). Critical mass can be very important in defining when an institution no longer relies on quotas or descriptive representatives to ensure female representation, or no longer keeps women from running male-centric institutions (Greed 2000). Once a constituency reaches a critical mass within that institution, they are in many ways no longer a minority. The processes and policies of that institution change with the changing demographics of its members (Grey 2006). Whether certain parts of the Cabinet are token slots for female officeholders or whether the Cabinet has achieved critical-mass for women is contingent on definition, but more importantly contingent upon time. Most crucially, tokenism and critical-mass show how informal gender stereotypes impact and shape structural advantages or disadvantages for women.

Time in this study is especially problematic due to the strides made by women since 1962. Cynthia Bowling found that female state bureaucracy chiefs have grown as a proportion from 5\% in the 1970s to $22 \%$ in the 1990s (Bowling 2006), keeping in line 
with ideas about critical-mass. Since 1962, women in legislative bodies worldwide have increased from practically nil to a significant bloc in those institutions (Mariani 2008). Egalitarian laws have been codified prohibiting discrimination against female employees in the government. The issue gender gap, wherein men and women as groups differ in opinion on policy direction, has been tied to the growing electoral gender gap between Democrats and Republicans; as women become more loyal Democratic voters, they tend to become more liberal over time (Kellstedt et al 2010). Female officeholders in 2011 differ widely in ideology and governing philosophy from their counterparts in the 1960s and 1970s.

At the same time, there are many factors that have remained relatively constant over time. Women in American politics rarely ascend to the highest leadership posts in the institution or their party (Borie-Holtz 2011). Women with family connections are most likely to have political experience (Jalalzai and Krook 2010). However, female candidates for office who appear to seek power for power's sake are often penalized for that posture by voters (Okimoto and Brescoll 2010). These findings indicate that some traditional gender norms persist.

The question of feminine traits also lends itself to suspicion when examined over time. A study by Richard Fox and Zoe Oxley (2003) analyzed traditional gender stereotypes in state elections from 1978 to 1998 . In that twenty-year period, feminist stereotypes have undoubtedly changed or been replaced, although the authors do not believe so. An experimental study examined so-called stereotypical feminine traits of warmth, gentleness, kindness, and passion compared to masculine traits of toughness, aggression, rationality, and assertion (Huddy and Terkildsen 1993) and found that the 
researchers were able to manipulate gender stereotypes by assigning alternating feminine and masculine traits to both male and female candidates for office. ${ }^{6}$ If researchers are able to manipulate gender stereotypes to show virtually no differences between male and female competence on foreign or domestic issues in a simple experiment (Huddy and Terkildsen 1993), it would be very difficult to assign a single set of gendered traits to individuals over the course of a 50-year study; during this time, women have entered the workforce, gained access to higher levels of education and employment opportunity, and by extension higher access in the echelons of government service.

As an example of changing norms, the four women who were appointed to the Cabinet in 2009 are the products of gender norms established in the 1970s and 1980s, whereas the women appointed to the Cabinet just twelve years earlier under Bill Clinton draw their life experiences from much further back in time. Some characteristics may stay universal; women who succeeded in Congressional advancement from state legislatures during the time period 1993-2002 tended to be younger than women who did not (Mariani 2008). These traits, however, are less important than perceptions of competence and leadership that researchers have tried to tie to gender (Fox and Lawless 2010; Fox and Oxley 2003; Greed 2000; Huddy and Terkildsen 1993); yet these researchers have been unable to reach consensus on what constitutes a gendered characteristic. Indeed, current research on gender traits in American politics is not uniform because gender traits themselves are not uniform.

The next step is to apply these concepts of femininity and masculinity to a 50-year long study about gender in the US Cabinet cognizant that not all gendered discrimination

\footnotetext{
${ }^{6}$ However, the authors argued that despite these findings there was still tremendous support that women were uniformly perceived as pro-compassion policies and men pro-military policies.
} 
can be accounted for by structural inequities. An objectively-defined, rational breakdown of the secretaries and Cabinet agencies will combine the findings of this body of research while acknowledging their transitory nature. For example, the 1992 "Year of the Woman" may be a launching point for many more liberal and feminist women's political careers; those women who started their political careers before or after that date may have differing political views (Kellstedt et al 2010). To conclude, the strength of gender norms across time may help explain a large portion of the variance in budgetary authority among male and female members of the Cabinet.

\section{The Federal Budget Process}

Leading officials in a modern presidential administration are not held accountable in the same way that elected officials are by a voting public. Much like private-sector employees, these figures serve at the pleasure of the president and have very few institutional mechanisms for removal. Moreover, their salaries are set at the same level for equal work. How then, would individuals seen as 'good' receive incentives through the system, while individuals perceived as 'bad' receive punishment? The budget's power of the purse incentivizes the bureaucracy to maintain standards of competence and accomplishment by rewarding successful programs with expansion and development while dooming outmoded or ineffectual programs with cuts or termination. Beyond that, lobbying groups may influence this process through efforts to keep unsuccessful but politically palatable programs funded, or by lobbying Congress and the presidency to implement new programs favorable to that interest group. In many ways the Cabinet acts 
as a lobbyist and a conducive agent for lobbyists; if the program in question exists in the secretary's department, that Cabinet official will strive to secure its funding.

Secretaries are further incentivized because the overarching goal of each bureau chief is success (Rubin 1993). In the US federal budget process, this success manifests itself as increased budgetary authority for the departments of each secretary. While the budget has not been described a zero-sum game, secretaries do extensively lobby Congress and the White House to support them in the annual budget battle for relatively scarce resources (Warshaw 1996; Cogan et al 1994; Rubin 1993). Deficit spending has grown to a level where a zero-sum game may indeed apply (Cogan et al 1994; Rubin 1993), but for most of the studied time period increases in budgetary expenditures for one agency did not constitute decreases for another agency. After consultation with the Cabinet, the presidency - which since 1974 has abrogated this responsibility through the Office of Management of the Budget (OMB) Director - compiles the budget and sends it to Congress for its approval and is usually paid for by 13 large appropriations bills each year (Dull and Patrick 2009; Benjamin 2001; Cogan et al 1994). Cabinet secretaries continue to lobby Congress both officially and unofficially to maximize the size of their budget authority (Rubin 1993).

The current complexity of the budget process, while somewhat more regulated since the 1974 Budget Act (Cogan et al 1994; Rubin 1993), leads to difficulties with operationalization or even basic description. Literature on the budget process can be described broadly as falling into two spheres. The first examines the process itself and draws understanding from rhetoric, public opinion for specific legislation, and political capital. The second sphere, to which this paper contributes, analyzes the myriad 
components and actors of the process, such as the Appropriations Committee in the House of Representatives, the perceived competence of the Cabinet secretaries, and the political affiliation of the president. Central to the construction and operationalization of these outputs is the Cabinet-Congressional relationship; while the White House is concerned with the totals of the budget, Congress (and implicitly the members of the bureaucracy spending these appropriated funds) are more concerned with the details (Cogan et al 1994).

The role of Congress in the budget process is constitutionally and traditionally defined as the power of the purse; the legislative body is the sole body to raise taxes and pay for spending bills, typically combined into the annual budget (Rubin 1993). Most budget bills originate in the House of Representatives or the Senate committees that deal with the budget, are passed and then sent to the floor of that house for passage (Benjamin 2001; Cogan et al 1994), and by tradition, spending bills originate in the House of Representatives (Sinclair 1997). After introduction, bills are referred to a committee or several committees for markup; since 1974 the Appropriations Committee acts on individual sections of the budget, such as Defense spending or funding for the Commerce department. The Budget Committee is often used to incorporate those pieces into a large omnibus spending bill (Sinclair 1997). Omnibus spending has become more palatable to Congress and the presidency in recent years, because in this way "many changes in policy can be made in one piece of legislation rather than in a number of separate bills, so fewer battles have to be won" (Sinclair 1997). During that process, the president's staff and the Cabinet lobby members of Congress to add amendments to the budget or push for certain parts of the budget that deal with their specific agencies or pet programs. Once 
passed, budgetary authority is released in increments as the bureaucracy requires funds, creating the separate amount known as budgetary outlays. After passage of the budget, the subcommittees of the Appropriations Committee dole out budgetary outlays as requested by federal departments for discretionary programs, while mandatory programs are funded through the committees that initially passed the legislation that created those programs (Sinclair 1997).

This study looks at that very crude measure of the budget process, budgetary outlays. Outlays are the outcome of the budget process, doled out over the course of a year, and in many instances the government spends monies in different agencies and towards different functions than a budget authority initially describes. The US Government Printing Office has budget authority data dispersed not by Cabinet but by function, which is why I used budget outlays (Cogan et al 1994). ${ }^{7}$ According to Cogan et. al (1994), both outlays and authority figures released by the OMB ought to be contested, but creating a dataset that would most accurately represent the real budget is impractical. The limitations of measuring budget outlays are noted, but for the purposes of conducting an effective and replicable study, outlays will suffice. Moreover, "A proper calculation of [expenditures for] current services...cannot be done mechanically or easily for many programs" (Cogan et. al 1994: 52). All attempts to measure gendered discrimination through the budget will thus require either a level of sophistication or simplification in order to be both valid and replicable (Cogan et al 1994). Fortunately, the budget outlays measure is unlikely to be systematically biased towards one gender or another, and if it is, would be the subject of a remarkable study unto itself. The budget

\footnotetext{
${ }^{7}$ Additionally, the 1976-1977 "Transitional Quarter" is omitted for this study due to the complexities of including a quarterly case in an otherwise annual case study.
} 
outlays data taken from the Government Printing Office constitutes the sole independent variable for this study.

Understanding the budget process is essential to understanding how a system of male privilege can remain in place despite enforcement of egalitarian laws and regulations. The OMB increasingly takes chatge of the packaging of the entire annual budget for presentation before Congress, often instituting a top-down leadership system where the president dictates his policy through the budget (Warshaw 1996; Cogan et al 1994; Rubin 1993). Cabinet heads are often assumed to be rational actors pursuing maximum benefits for their bureau. In this sense budget increases are seen as the goal, not program success, although this is not a universal trait of bureau chiefs (Rubin 1993). Finally, the role of Congress in the budget often depends on the perspective of Congressmen; many members of the legislature see themselves as representatives on behalf of a constituency or group of constituencies while others see their role as to enact certain policies (Rubin 1993). The other main budget-related data collected were the annual inflation rate from 1962-2010. If not taken into account, inflation would benefit the annual budget increases of modern Cabinet secretaries.

\section{Summary of Key Theoretical Concepts .}

The literatures on male privilege, femininity, and the budget process interact when there are women in the Cabinet. Informed by superficial qualities such as sex, ${ }^{8}$ members of Congress form a constituency through which they judge the competence and value of the members of the Cabinet. Competent Cabinet secretaries will be rewarded

\footnotetext{
${ }^{8}$ Sex, like race, is largely seen as a biological reproductive attribute. Gender is created by societal norms and influences behavior. In this paper, I examine sex as a superficial, biological attribute rather than the attribute of gender formed for an individual by themselves and society.
} 
with larger vote share via Senate confirmation votes and House appropriations subcommittee votes, but most importantly competence will be expressed through increased budget size. Secretaries perceived as incompetent will be punished by their constituency via lower vote share and relative or absolute decreases in the size of their departmental budgets.

The actors comprising the presidency, Congress, and the Cabinet secretaries form the inputs that then compete in the obscured, amorphous, and evolving world of the budget process. Inclusion of all the factors in the budget process is beyond the scope of this paper, but certain inputs must be accounted for. Mandatory spending programs such as Social Security, Medicare/Medicaid, and interest on the debt are the fastest-growing part of the budget and are largely out of lawmakers' hands (Cogan et. al 1994). Inflation is also necessary for this model given that all of the budgets of the Cabinet grow to adjust for inflation and such growth would likely distort findings. Inflation and mandatory spending have a massive impact on the budget since they are largely beyond the control of appropriators and bureaucrats in the federal government. In particular, mandatory spending programs are often designed to last for a set amount of time and remain unchanged in annual spending bills (Cogan et al 1994).

This paper will take these factors and insert gender into the Cabinet, and to a lesser extent Congress, to determine if male privilege manifests itself in the federal government through the budget process. Structural discriminators, such as the nature of advancement in Congress or certain bureaucratic agencies, will be balanced with informal gender inequities, such as the theories of tokenism, critical mass, and femininity. As discussed before, these different forms of gender discrimination often work in tandem to 
create a pervasive environment that advantages male officeholders to the detriment of their female peers. Whether or not structural or informal types of inequity inflict more harm to female Cabinet members will be a major focus.

Combined, these variables provide a good way to examine the inputs and outputs of the complex budget process and the influence of gender upon the budget. While I admit that new literature may need to be added if new concepts are inserted into the model, these ideas provide the foundation in the literature that I will then operationalize for analysis. Though the process itself may be very difficult to quantify, ${ }^{9}$ as long as the process yields roughly the same outcome (funding the government), change in the inputs and outputs will give us useful information about the nature of gender discrimination in the US Cabinet. Literature on gender bias in the federal executive branch is still developing, but it is more than sufficient for the purposes of providing direction and data for this study.

\footnotetext{
${ }^{9}$ Concepts such as the 'quality' of the budget are completely subjective but can make a powerful difference in the real world. 'Good' administrators will provide services to constituencies whereas 'bad' administrators will squander publicly-appropriated funds. Any attempt to measure this outcome is far beyond the scope of any single paper or author.
} 


\section{CHAPTER THREE}

\section{DATA AND METHODS}

\section{Primary Data Collection}

The dataset consists of data extracted from a wide variety of sources, ranging from the Government Printing Office's (GPO) annual budget report to biographies of the individual members of the US Cabinet over a 50-year time period. Moreover, as the model developed from thinking in terms of two variables into a larger, more comprehensive vision of the budget process, variables from even more diverse sources were required. As such this dataset is in many ways unique and unorthodox.

The first steps were to collect data on the sex of members of the Cabinet as well as budgetary data. The measure of budgetary outlays as reported by the Bureau of Labor Statistics (BLS) was recorded as the sole outcome measure of the budget process (GPOAccess.gov, 2011). All data were reported in numeric terms not adjusted for inflation. Budgetary outlays are the combined totals of funding spent over the fiscal year by each Cabinet agency. The GPO reports a second way to view budgetary expenditures: budgetary authority, the amount of money Congress initially appropriates funding to the Cabinet agencies at the start of each fiscal year rather than the amount actually spent over the course of that fiscal year. Moreover, both budgetary outlays and budgetary authority 
are reported by the fiscal rather than the calendar year, unlike all other variables which are reported only in terms of the calendar year. ${ }^{10}$

Although budgetary authority data would be more useful for this model, two characteristics of the data made it unreliable for research. First, budgetary authority is reported by function rather than by agency, which would require a very in-depth, timeconsuming collection of data in order to match budgetary variables with other variables in the model, and there would be no guarantee that the functions reported did not fall under the purview of two or more Cabinet agencies simultaneously. Secondly, budgetary authority does not actually reflect expenditures but merely the expectation of program spending. On the other hand, budgetary authority most likely resembles the funding requests that Cabinet members send to the OMB. In the end, budgetary outlays were most useful as a measure that would be both replicable and objective. This paper does not try to resolve the fiscal-year versus calendar-year discrepancy, but acknowledges that the model is not fully accurate as it stands. After compiling budgetary-outlays data from 1962-2011, I used a Log 10 transformation on the variable to achieve normal distribution.

The sex of the secretaries was the primary predictor variable. In the time period analyzed, there have been no publicly transgender or homosexual Cabinet members, meaning that the only categories were heterosexual male and female, operationalized as a dummy variable." Given that many Cabinet officials resign midway through their term, whenever two or more persons occupied any particular Cabinet post in the same calendar year, the person with the most time spent that year in the Cabinet was coded as the

\footnotetext{
${ }^{10}$ Most members of the Cabinet, presidency, and Congress serve January-to-January terms, and are effectively calendar-year terms given the historical paucity of legislation in the first few weeks of the new year.

${ }^{11} 1=$ Female, $0=$ Not Female
} 
secretary for that entire year. ${ }^{12}$ From this variable, two more characterizations of female representation in the Cabinet were operationalized. First, I created a variable reporting the number of currently-employed women in the entire Cabinet in each year from 1962$2011 .^{13}$ Second, I created a variable reporting the number of women who have ever served as secretary in each Department. ${ }^{14}$ These alternate categorizations of sex are intended to test notions of critical mass for particular presidential administrations or for particular departments. For example, the Department of Defense has never had a female secretary, but the Department of Labor has had seven female secretaries since Frances Perkins in 1933. These alternate definitions of sex - by department or by Cabinet rather than by individual - may be more useful measures of gender discrimination. It may be that men and women are not perceived differently by the major actors in the budget process, but certain periods of time or certain agencies are perceived as more masculine or feminine. ${ }^{15}$ The question to code secretaries as either descriptive/generalists or substantive/specialists would be subject to a tremendous amount of subjectivity, so I assume that women who are generalists have less access to informal networks inside Washington than male generalists, and that female specialists in the Cabinet are not taken as seriously as contemporary male specialists in a uniform manner. The personalities of Cabinet secretaries would similarly be a difficult measure to operationalize; so no

\footnotetext{
${ }^{12}$ This was mostly a problem during the 1970s, especially when the Nixon Administration had several waves of resignations during the Watergate scandal.

${ }^{13}$ In 1962 there were no female Cabinet members, so 1962 is coded as 0 . In 2011, there were four female secretaries, so 2011 is coded as 4 .

${ }^{14}$ In 1996, no women had served as Secretary of State, so the State department would be coded in 1996 as 0. By 2011, Madeleine Albright, Condoleezza Rice, and Hillary Clinton had all served as Secretary of State, so the State department in 2011 would be coded as 3 .

${ }^{15}$ As with the literature review I acknowledge that the terms 'masculine' and 'feminine' are not necessarily synonymous with 'male' and 'female' and that masculinity and femininity are very subjective terms. For the purposes of this paper, I posit that the more women in an administration or in a Department is associated with that administration or that Department, while arguing that these alternate forms of gender may account for entirely different forms of gender discrimination beyond masculinity or femininity.
} 
measure of personality type was included in this study. This study does not ask the causal question of government priorities; are female secretaries placed as secretaries of agencies deprioritized by the nation, or do departments lose priority after the presence of women? Ultimately, the measure of sex by gender may shed some light on that question without truly resolving it.

\section{Predictor Variables}

The dataset thus comprises 639 case-years, broken down by the number of years each department has existed since $1962 .{ }^{16}$ After compiling the sex of the Cabinet secretaries from 1962-2011 and the expenditures of those agencies over the same time period, I constructed a multivariate model that should explain how the budget process operates based on the literature review. Each year, the budget is formed when the Cabinet submits its budget requests to the president and Congress, who turn those requests into legislation on which they vote. During this time, members of the Cabinet lobby Congress and the president to prioritize their budget requests. After the budget is passed, Congress votes from time to time to dole out money to the Cabinet as those agencies require funding; during this time as well the members of the Cabinet extensively lobby Congress to provide sufficient funding to government programs. Successful Cabinet members are those who receive the largest possible budget allocation from Congress. Votes on the budget and secretaries in the Cabinet should, in part, capture how the constituency of Congress perceives the competence of the public official in the Cabinet at the conclusion of this lobbying process. Variables that account for this

\footnotetext{
${ }^{16}$ The dataset is constructed so that the Departments that existed pre-1962 in some form, including HHS' predecessor HEW, are represented by 50 case-years from 1962-2011. Departments such as Education and Energy will only have as many cases as they have been granted full Cabinet-level status.
} 
complex system would thus have to simultaneously capture the nature of the budget process as well as the personal and professional characteristics of the constituent actors. Variables that would accomplish this task fall into four broad groups: personal characteristics of the secretaries of the Cabinet; partisan characteristics of Congress and the presidency and the sexed demographics of Congress; Senate confirmation votes of the members of the Cabinet and House appropriations votes on the budget; and control variables to account for mandatory spending programs and inflation. Each set of variables will be described at length below.

Variables that constituted the personal and professional characteristics of secretaries in the Cabinet (including gender) were drawn from a wide variety of sources (Justice.gov 2011; State.gov 2011; Federal Staff Directory, 2006-2010; Sobel and Sicilia 2003; Vexler 1975). Determining which variables were necessary for the utility of the model and which were not was a very difficult task. Research in the literature suggests that there are no consensus traits that politicians advancing through the pipeline all possess. Moreover, the 50-year time span of the study meant that I would not have access to uniform information deemed relevant by archivists of the 1960 s and the 2000 s. Thus, the variables chosen were those that matched the body of literature, suggesting what personal traits constituents find salient as well as those that were universally reported. The traits selected are education, career choice, government experience, marital status, and the number of children/family size of the secretary.

The highest level of education attained by a secretary provides the most explanatory power. In addition to showing their academic prowess, the level of education reveals personal ambition and implies the status of the secretary's family: 
wealthier families are more capable of sending their children off to postgraduate schooling. In the Cabinet, the overwhelming majority of secretaries held postbaccalaureate degrees, so the variable was coded as a dummy variable. ${ }^{17}$ While there may be differences between those with college educations and high school educations, neither group provided any major dissimilarity compared with the distinction between secretaries with postgraduate degrees and secretaries without such degrees.

The literature on the pipeline suggests the career of a secretary is a very influential predictor of candidate success. Prior research identifies business and law as the most likely fields for public servants to have held while in the private sector. Researchers also noted that these are two career fields in which women have encountered significant difficulty achieving gender parity. For this study, two dummy variables were created, one for a law career and another for a business career. ${ }^{18}$ When a secretary's biography showed two non-governmental careers, the career of longest duration was chosen. Law careers consisted of any and all legal work, including lawyers and paralegals. Business careers consisted of all private-sector work that was not academic, military, union, social work, or law-related.

The literature does not highlight prior government experience as a necessary requirement for advancement through the pipeline; instead, much of the literature review suggests that youthful candidates in state legislatures have a better chance of advancement to Congress or a state executive office. However, the Cabinet is often a final career post for many public servants, and I hypothesize that Cabinet members with a more intuitive feel for the system and the budget process, based upon their experiences

\footnotetext{
${ }^{17} 1$ = Postgraduate education, $0=$ No Postgraduate (post-baccalaureate) education

${ }^{18} 1$ = Law career, $0=$ Not Law career; $1=$ Business career, $0=$ Not Business career (separate variables)
} 
and connections, will have more success in procuring larger funding boosts than their relatively novice colleagues. This variable is coded for the number of years of prior government service, excluding mandatory military service and private-sector consulting contracts with the government.

Marital status is a difficult characteristic to operationalize. American society has constantly evolving standards of what constitutes acceptable behavior on the part of public officials. Presidential or congressional sexual affairs (predominantly those where the officeholder was a man) were tolerated much more in the $1960 \mathrm{~s}$ and 1970s than today, while views on homosexuality, unmarried women, and remarried men and women have become more accepting. This study does not attempt to resolve any of the difficulties of measuring marital status; instead, I adhere to an assumption that the traditional 'nuclear family' is the most desired public image a politician wishes to convey, while those who have never married or have divorced and not remarried do not fit within the norm of the nuclear family. Operationalization of this characteristic resulted in the creation of two dummy variables and a reference variable. ${ }^{19} \mathrm{My}$ distinction between those who have divorced and those who have never married is guided by the assumption that male members of the Cabinet were more likely divorcees whereas professional women were more likely than professional men to have never married. The data support this belief (See Table 1); the majority of remarried secretaries have been men whereas the majority of never-married secretaries have been women. If the results align with expectations from the literature, remarried secretaries will not face the same stigma that unmarried women face in the eye of public scrutiny. Other descriptive

${ }^{19} 1$ = Married, Remarried, or Widowed, $0=$ Not Married, Remarried, or Widowed; $1=$ Never Married, $0=$ Not Never Married; $1=$ Divorced but not Remarried, $0=$ Never Divorced without Remarrying. The variable for divorce was used as the reference variable. 
statistics (see Tables 1 and 2) suggest that female secretaries are much less likely to have worked in business careers, are much more likely to have never been married, and are over-represented in the State, Labor, and HHS departments.

The final personal characteristic deals with the size of the family, measured by the number of children of the secretary at the time of nomination. This variable reflects the belief that candidates who resemble the nuclear family of one to three children will be advantaged relative to secretaries with larger families, which in and of themselves implies certain ethnic or religious connotations, specifically that secretaries from nonnormative backgrounds such as Catholicism or Mormonism would be discriminated against. Secretaries with no children are a very small subset of the population, and while not explicitly analyzed in this study, I would assume that female secretaries with no children would be treated very differently than male secretaries with no children. If in the course of the future a sufficient sample size of childless secretaries of both sexes emerges, this project is prepared to examine those advantages and disadvantages. For this paper, I hypothesize that secretaries with larger family sizes will be viewed less favorably than secretaries whose families resemble the idealized nuclear family.

Measures of partisan control over the institutions of Congress and the White House were compiled from government sources that report the partisan makeup of those institutions. The measure of the number of women in Congress came from the Congressional Research Service's report on the historical status of women in Congress (CRS 2011). In total, four variables were created to describe how partisanship and the gendered breakdown of Congress affect the budget process and the makeup of the 
Cabinet: partisan orientation of the President, ${ }^{20}$ two dummy variables indicating control of both houses of Congress, ${ }^{21}$ and the number of women in Congress.

For the time being, I assume that the GOP has been since 1962 the party of limited federal government spending, and that Republican control of either the presidency or the two houses of Congress will result in either relative or absolute reductions in the federal budget. Conversely, Democrats have long been commonly associated with support for federal assistance in the welfare of a large number of constituent groups and support for government programs that provide a wide number of government services. In this paper, I assume that the size of government spending would grow whenever the presidency or both houses of Congress are controlled by the Democratic Party.

The variable accounting for the number of women in Congress is predicated on tests by researchers that representatives will help like-minded constituencies. In this case, I posit that as the number of women in both the Cabinet and Congress increases, government expenditures will increase; funding for female-friendly government programs exacerbated by the trend among women towards the Democratic Party, are sufficient evidence to warrant inclusion of this variable.

Votes in the Senate to confirm Cabinet nominees and in the House to appropriate funding to federal agencies were drawn from the offices of the Historian of the Senate as well as from the Library of Congress (Senate.gov 2011). The logic behind reporting these votes was to record Congressional approval for Cabinet secretaries over time; both the Senate's initial opinion of the secretary and their continuing approval or disapproval

\footnotetext{
${ }^{20} 1$ = Democratic President, $0=$ Republican President. Coding was intended to suggest that Democrats favor women's issues and reflects literature showing that the Democratic Party enables the advancement of female candidates.

${ }^{21} 1$ = Democratic Control of both Houses, $0=$ Not Democratic Control of both Houses; $1=$ Republican Control of both Houses, $0=$ Not Republican Control of both Houses.
} 
of the secretary's performance are measured in part with these votes. If a secretary was not viewed as competent by Congress, we would expect declining affirmative votes on that secretary or votes on that secretary's budget to mirror a relative or absolute decline in that secretary's departmental budget. Variance among the myriad confirmation votes is not optimal; no member of the Cabinet was rejected as a nominee and most nominees are approved in unanimous voice votes or unanimous-consent votes. Recorded votes on every nominee became commonplace in the past 30 years, symptomatic of growing partisanship in Washington. Publicly, the Senate has recorded votes only from 1977 to the present day but after a brief inquiry, the Senate office of the historian provided votes, both recorded and unanimous, back to $1789 .^{22}$

The office of the Senate also provided, in conjunction with the Library of Congress' Thomas.gov website, the necessary data for House votes on each Appropriations subcommittee budget bill going back to 1986 . The way the budget process operates varies from year to year, but each Appropriations subcommittee is still obligated to pass a bill authorizing funding for the departments under their purview. The number of subcommittees has varied somewhat over the time period analyzed in this study, but each Cabinet department has been covered by a subcommittee and therefore has a recorded vote from 1986-2011; a record of prior votes is not available.

Variables controlling for inflation and mandatory-spending programs were taken from the GPO report and the BLS Consumer Price Index (GPOAccess 2011; BLS.gov 2011). Mandatory spending programs are not reported in the same manner as budgetary outlays, but similar to budgetary authority, by function or specific government program.

\footnotetext{
${ }^{22}$ The office of the Historian of the Senate provided me with a record of Senate votes from 1789-1985 compiled by the Senate's Congressional Research Service Report No. 85-1120 by Rogelio Garcia.
} 
Coding this variable was further compounded by the possibility that government programs switch between various agencies within the Cabinet. Fortunately, no mandatory programs selected were run out of more than one government agency and were run out of that agency for the entirety of the time period. However, several mandatory programs were omitted due to said complications. Most importantly, Social Security (which accounts for almost a quarter of the federal budget) is not represented in this study at all because it is run out of the Social Security Trust Fund and is not under the direct control of any Cabinet-level agency. Additionally, some mandatory programs have been profitable, meaning that there were several case-years coded in negative numbers. The largest mandatory government programs included in this study are Medicare/Medicaid, agricultural subsidies, and interest on the federal public debt, while the State, Labor, Energy, Defense, and Veterans' Affairs departments run smaller mandatory-expenditures programs.

\section{Methodology}

The resulting dataset provides the empirical basis for understanding how gender in the Cabinet impacts the budget process. For this study, an ordinary least squares regression model is the primary statistical tool used to analyze the hypothesized relationships. Initial tests were descriptive in nature in order to ensure that variables were coded successfully (see Tables 1,2, and 3). These cross-tabular analyses introduce the data in an accessible manner and allow examination of key variables to see if theoretical assumptions pass muster on a superficial level. From the cross-tabular analysis breaking down variables by sex (see Table 1), we see that female Cabinet secretaries are more 
likely to have advanced degrees, less likely to have a business degree, and are much more likely to have been nominated when single. These expectations largely match assumptions outlined in the literature review about the nature of female officeholders. Other descriptive findings are less intuitive; roughly one-third of all female and male Cabinet secretaries had law careers before taking up public service. In some ways, this finding is more interesting because it shows hard data to counter some of the more egregious stereotypical beliefs about female public servants.

Other descriptive findings display the breakdown of Cabinet departments and presidential administrations by some of the predictor variables in the model. With these charts some of the other theoretical postulations about the nature of the Cabinet come into focus. As an example, lawyers tend to get placed in the Justice Department and secretaries with business backgrounds tend to get placed in the Commerce and Treasury departments (see Table 2). Over half of all female secretaries were nominated under Democratic Presidents, but a majority of female secretaries have been nominated during times of Republican or split control of Congress. Rounding out results broken down by sex, roughly equal proportion of lawyers in the Cabinet have been male or female, and male secretaries have five more years public experience on average than female secretaries.

Descriptive statistics subdivided by presidential administration highlight other interesting findings. Democratic presidents have nominated a disproportionately larger share of secretaries with law degrees, whereas Republican presidents nominate more businesspersons (see Table 3). Finally, while more women have been nominated to the Cabinet under Democratic presidencies, more women have been nominated to the 
Cabinet under Republican-controlled Congresses, an expected finding given that the Democrats controlled Congress for all of the 1960s and 1970s when there were three Democratic presidents but no female Cabinet members.

Next, bivariate correlations were run between key variables to test the major assumptions of this model. Each measure of sex was tested against the dependent variable, as well as the independent variables measuring Senate confirmation votes and measures of the partisan control of chambers of Congress and the presidency. However, most correlations in this study should be taken with a grain of salt due to the long durations of time in the study; assumptions about the nature of federal governing institutions in the 1960s may be substantively different than assumptions made about government in the 2000 s, such as how seriously the Senate takes the family size of candidates back in the 1960s when public officials had much more privacy.

Preliminary regressions were used to test some of the key assumptions behind my model. First, I established the measure of Senate confirmation votes as a dependent variable and the personal characteristics measures as the independent variables for 19622011. For the 1986-2011 time period, the measure of House appropriations votes was used as the dependent variable and personal characteristics measures as the independent variables, along with measures of partisan affiliation and the number of women in Congress. These models test the assumption that the Senate's initial perception of candidates take into account personal traits in addition to partisanship, and that House subcommittees take both partisanship and personal characteristics into their deliberations over whether or not government agencies require surplus funding. 
I then tested my models with a series of OLS equations. Each measure of gender was inserted alongside all of the other personal characteristics, partisan affiliation measures, voting measures, and control variables for a total of three model variants that encompass the time period of 1962-2011 and another three model variants that encompass the time period 1986-2011 in order to include House Appropriations Committee subcommittee votes on the budget process. ${ }^{23}$

After running these models, two time counters were inserted, creating a set of three more models from 1962-2011 for each time counter. The first time counter was a dummy variable that would account for the somewhat abrupt transformation of Congress in the 1992 elections. $^{24}$ Not only was it a banner year for female Congressional candidates as a result of the 1992 elections, but early in the year George H.W. Bush nominated Barbara Franklin to be only the second female Commerce Secretary and made his administration only the second to have two female secretaries. The second time counter was an interval counter by year. ${ }^{25}$ This variable assumes that each year, the nation becomes slightly more progressive, more partisan, and that female legislators and Cabinet members increasingly associate themselves with the Democratic Party. Ideally, increasing partisanship in the Senate will result in fewer affirmative confirmation votes as well as affirmative House budget votes. The time period 1986-2011 did not have a time counter applied due to its relative proximity to 1992 .

\footnotetext{
${ }^{23}$ The 1986-2011 dataset was created by eliminating all cases from the original dataset. With the exception of the House appropriations votes variable, I made no other changes to the 1986-2011 data.

${ }^{24} 1=1992-2011,0<1992$

${ }^{25} 1962=1,1962=2,1963=3$, etc.
} 


\section{Hypotheses}

While OLS cannot be used to confirm causality, this model is constructed on the idea that discrimination is pervasive throughout the elite institutions of the US government. My hypotheses will thus be couched in the language of probability, where rejected null hypotheses would not reject expected outcomes. An expected outcome would suggest that sexual discrimination does indeed exist in the budget process. Null hypotheses will test my theoretical assumptions.

$\mathrm{H}_{1}$ : Sex of the secretaries of the Cabinet (as measured by the three operationalizations of gender) has no significant effect on the size of that secretary's annual federal budget.

$\mathrm{H}_{2}$ : Variance between secretaries measured by other personal characteristics - a secretary's highest level of education, prior government experience, a career in business or the law, marital status, or family size - will have no significant effect on the size of that secretary's annual federal budget.

$\mathrm{H}_{3}$ : The partisan affiliation of each branch of Congress, or of the presidency, will have no significant effect on the size of that secretary's annual federal budget. The number of women in Congress will have no significant effect on the size of that secretary's annual federal budget.

$\mathrm{H}_{4}$ : Variance between secretaries measured by Senate confirmation votes and House Appropriations Committee votes on the annual budget will have no significant effect on the size of that secretary's annual federal budget. 


\section{CHAPTER FOUR}

\section{Bivariate Discussion}

\section{FINDINGS}

Two sets of bivariate correlations were run: the first, where predictor variables were run against the variable coding for the individual sex of Cabinet secretaries, and the other where predictor variables were run with the dependent variable, budget outlays. Since all hypotheses are null hypotheses, all significant correlations with positive or negative directionality reject those hypotheses. However, the rejection of null hypotheses of these relationships does not reject assumptions outlined in the literature review that expect certain variables to positively or negatively correlate with sex and budget growth. The findings show that many relationships do indeed reject the null hypotheses and confirm many of the underlying assumptions of pervasive gender discrimination in the federal budget process. In this paper, I categorize results into three groups: confirming, counterintuitive, and contingent findings, and will report them in that manner.

Fortunately, a number of relationships reflect findings from other scholarship on the nature of male privilege and gender discrimination in the public sector. There is a negative

correlation between female secretaries and secretaries with a business career, showing that business is still a male-dominated career from which politicians advance through the pipeline. The two dummy variables coding for marital status confirm that female Cabinet secretaries remain unmarried at a higher rate than male secretaries, and 
that female secretaries have fewer children than male secretaries. Even more interestingly, secretaries with more children are less likely to receive budget increases than those with fewer children. Also as expected, as the numbers of women in Congress increase, so does the chance that any particular secretary is a woman. The numbers of affirmative Senate confirmation votes are more likely to decrease if the nominee for a particular Cabinet position is female, and House Appropriations Committee votes are more likely to decrease when the secretary in charge of an agency is a woman. Secretaries with post-baccalaureate degrees are more likely to receive larger budget increases, as are secretaries who do not marry.

Despite many expected outcomes, these correlations reveal several counterintuitive results. The correlation most likely to 'make or break' the model, comparing sex of secretaries to budget outlays, is statistically significant but does not confirm the null hypothesis nor the expected directionality, showing instead a weak positive relationship. This would suggest that discrimination exists but discrimination occurs against male secretaries, not female secretaries. A law degree is negatively related to the increase in departmental expenditures, suggesting that a law degree may not adequately prepare public officials for the rigors of bureaucracy. Interestingly, prior government experience is statistically significant when correlated with budget outlays and shows a positive relationship, but is not significantly related to the sex of the secretary.

Variables accounting for partisanship in Congress and the presidency perform counter intuitively. The partisan affiliation of the president confirms the null hypothesis but may reject prevailing attitudes about the relationship between women and the 
Republican party; female secretaries are only slightly more likely to have been nominated by a Democratic president than a Republican president, and neither Democratic nor Republican presidents are more likely to receive larger budget increases for their Cabinets. Congressional partisans act in an even less intuitive manner. So-called smallgovernment Republicans are positively correlated to larger budget increases and a greater likelihood that any given Secretary is a woman, whereas allegedly big-government Democrats are inversely correlated with larger budgets and the number of female secretaries. While some of these inconsistencies can be explained by the 50-year passage of time, it may very well be that Republicans use the bureaucracy to appeal to women as a constituency and Democrats do not.

The incongruities in these correlations may suggest several potential explanations. First, the theoretical constructs that led me to assemble this model may be incorrect; while the pipeline theory may explain the behavior of legislators, the constituentrepresentative relationship may not exist between Congress and the Cabinet. Secondly, it may be that Republicans are not always the small-government conservatives they claim to be while Democrats are not always the big-spenders as they are portrayed in mainstream media outlets. Third, the theory of male privilege may need amending to include the concept of female privilege.

\section{Multivariate Regression Discussion}

Six ordinary-least squares regressions without any time counter were run and yielded a mixture of expected and unexpected results. In the section of variables accounting for the personal characteristics of Cabinet secretaries, those secretaries with 
post-baccalaureate degrees and prior government experience before nomination to the Cabinet were more likely to see increased budgetary expenditures relative to their colleagues. A positive coefficient existed with secretaries who had been married, remarried, or widowed ${ }^{26}$ as well as those secretaries who had never married, suggesting that the subset of divorced but not remarried secretaries was the only subset that was likely to see budget decreases relative to their colleagues. As expected, inflation is significant and has positive directionality for the 1962-2011 model, but not for the 19862011 model. Finally, significant across all six models were Senate confirmation votes and the proportion of women in Congress; however, the coefficients were relatively weak.

Other coefficients were significant depending on the model. In particular, the variable accounting for sex was only sporadically significant and its directionality was not consistent. From 1962-2011, only the measure of sex by the number of women in the Cabinet was significant, and it was positively associated with budget increases. However, from 1986-2011, the other two measures of sex were highly significant but negatively associated with budget increases. Given that all variables were coded so that positive outcomes would show that the budget process favored women, the discrepancy is confusing and counterintuitive. Essentially, it suggests that from 1962-2011, presidencies with more female Cabinet secretaries were more likely to spend larger budgets, but that from 1986-2011 that relationship disappears and is replaced by a phenomenon where women themselves and departments that favor female leadership are subject to discrimination.

\footnotetext{
${ }^{26}$ And thus fit the acceptable types of marital status that embody the typical nuclear family, as opposed to those secretaries who were divorced and not remarried or those who had never married.
} 
As found in the correlations section, there is no relationship between a business career and increased budgetary outlays, and there is a negative relationship between secretaries with law careers and the growth of those secretaries' departmental budgets. This is completely inconsistent with prior academic literature on the subject that suggested successful businesspersons and lawyers would advance through the pipeline to the top. Given that competence and performance are powerful predictors of advancement, these findings would appear to reject the idea that lawyers and businesspersons make 'better' Cabinet members.

Findings concerning partisanship of the presidency and Congress suggest that the results discussed in the correlations section are only appropriate for the full time period; from 1986-2011 no measure of partisanship was statistically significant. However, for the full time period it would appear that Democrats are actually the party of smaller government (see Table 2) as both the Democratic control of Congress and the party of the president variables are negatively associated with larger spending for any particular Cabinet agency.

Other tenuous findings included the variable accounting for family size and the variable accounting for mandatory expenditures. In no version of the model is there a strong connection between family size and variation in budgetary expenditures. This is likely because there are very few families of Cabinet members with a very large number of children. The variable accounting for mandatory expenditures is highly statistically significant, but the coefficient is very weak. Part of this is for the inconsistent way mandatory programs are set up and coded; several departments have no mandatory expenditures at all, while others are reported by the GPO as negative sums suggesting 
that these programs are profitable. For this study, the figures reported by the GPO are represented faithfully. It is possible that alternate coding structures would more accurately reflect how mandatory programs affect the budget process.

Finally, the model below explains slightly less than half of the variance in the budget process. Given the wide array of informal mechanisms in Congress and the bureaucracy, that this model is able to explain $48-51 \%$ of the variance suggests that these variables do have some relevance to the budget process. Undoubtedly other variables not included have predictive power, but this model captures many of the actors in the system and faithfully sets up how gender discrimination would operate in said system.

\section{Discussion of Time Counters}

The original model's major flaw is that it fails to account for the passage of time. Many of these results can be explained by the transitory nature of Congress, the Cabinet, and the budget process. I chose to use time counters as a solution for this problem. The first time counter is a dummy variable intended to account for the disparities in the number of women in Congress and the Cabinet before and after 1992. ${ }^{27}$ Many of the same variables retain their prior characteristics, including those variables representing levels of education attained, prior government experience, law or business career backgrounds, and the control variables for inflation and mandatory government expenditures. However, time clearly had an impact on one measure of sex, that of sex by the number of women to have led a given department. A positive, statistically significant coefficient is reported, compared to the negative and not significant coefficient reported

\footnotetext{
${ }^{27}$ Time counters were not employed for the 1986-2011 variants of the model due to the relatively short time period.
} 
without the time counter. The wide variance of the various measures of sex will be discussed at length in the concluding section, but for this particular measure it is very useful that this finding was statistically significant. Were all measures of sex insignificant, I would expect that Cabinet departments were not led by women consistently nor had any given department ever been run by an above-average or belowaverage number of female secretaries over the 50-year time span. Given that the Department of Defense has never been led by a woman and the Department of Labor has been led by seven, this report shows the utility of controlling for time in a time period of considerable longevity.

After controlling for time, it appears that the marital status of secretaries becomes less relevant; the strength of positive coefficients for those secretaries who were married, remarried, or widowed is reduced compared to the original model. Increasing tolerance for 'non-traditional' families in the past twenty years likely explains this change. Finally, the variables concerning partisanship have weakened substantially as compared to the initial model, likely due to the discrepancy on fiscal values between rhetoric and action when either party commanded complete control over Congress and the presidency.

The time counter itself has a positive coefficient, confirming that budgets post1991 are much larger than those before 1992 even after accounting for inflation This is expected given the expansion of government programs and services in the past 20 years. The addition of the counter also has a powerful effect on the R-square value, jumping from explaining slightly under half the variance to explain roughly $63 \%$ of the variance. Again, this is welcome news; if the insertion of a time counter did not explain part of the reason behind the annual growth in budgetary allocation, the model would be suspect. 
Departments such as HHS and Defense have seen consistent increases in their budgets beyond the rate of inflation, and new departments such as Education and Energy were created after 1962. Were the time counter to lack significance or to show no directionality, it would suggest that the expansion of the government in the past 50 years had not happened.

The second time counter was constructed to represent the steady flow of time rather than to select a fixed point in time. This interval counter would not only account for the haphazard way that generational change occurs, but also capture the slow growth of both hyperpartisanship and the gender gap in Washington. As before, when compared to the initial model, many of the same variables remain unchanged in both significance and directionality, including variables accounting for post-baccalaureate education, prior government experience, law or business backgrounds, and marital status.

The biggest changes occur among the three measures of sex. The interval time counter reverses the significance of each variable; the measure of sex by individual secretaries and the measure of sex by women in each department are now statistically significant and are negatively associated with budgetary expenditure growth. The measure of sex by the number of women in the Cabinet for each administration now appears as not statistically significant.

Other large changes include partisan indicators, none of which now register as significant, and the variable accounting for the number of women in Congress, which now shows negative a relationship to the growth of departmental budgets. Secondly, inflation is no longer statistically significant, which confirms the utility of an interval time counter. Were inflation still to occur year by year, I would assume that the time 
counter was not reliably coded. In this variant of the model, the number of children is significant and negatively associated with growing budgetary expenditures. The interval time counter does not have as strong a coefficient as the dummy time counter, but nonetheless is significant and positively-associated with the growth in budgetary outlays. Unlike the dummy counter, however, this interval time counter does not explain a sizeable portion of the variance in the growth of budgetary outlays, increasing the Rsquare value from slightly under $50 \%$ to $53 \%$ in each of the three variations of the model.

\section{Confirming, Counterintuitive, and Contingent Results}

Combined, these results paint a picture of a budget process with several confirming results, several counterintuitive results, and several results that I label 'contingent'. In the category I label 'confirming', I place many of the personal characteristics variables such as prior government experience, education level achieved, and business careers. These variables do not change based on the implementation of time counters or the insertion of new variables and time periods. Secretaries with postgraduate degrees were consistently more likely to see larger budget revenues than those secretaries without postgraduate degrees, as are those secretaries with more prior government experience. In both cases the size of coefficients remained very stable; they are indicative of the manner in which confirming findings behave. Were further research on this subject to be extended into the past, or continued into the future, I would not expect these variables to change substantially.

Although they maintain stability across all variants of the model, these confirming variables are not completely in line with expectations. House Appropriations Committee 
votes appear briefly in the 1986-2011 section, but appear to lack statistical significance and clear directionality, so while they are consistent, they consistently lack impact. If my study were to expand further in time in either direction, I would expect these votes to have some relevance. Finally, the relationship between budgetary increases and prior government experience is much weaker than I expected, wherein each year of additional service contributes very little to Congressional perceptions of a secretary's competence. Only those Cabinet secretaries with very long careers in public service are predicted to see substantial budgetary growth.

In the counterintuitive category I place partisanship indicators, a career in the legal profession, and marital status. It appears that advocates of small government should not expect full Republican control of Congress or the presidency to reduce federal programs and services in any meaningful way compared to split control of Congress or even Democratic control. Likewise, proponents of using the federal government as a means for promoting social welfare and economic redistribution should not expect Democratic control of the levers of power in Washington to affect substantially more spending than other partisan configurations. The variables controlling for marital status show that while secretaries who fit the mold of the traditional family are more likely to benefit from the budget process, secretaries who have never married are also beneficiaries of this system. The only marital category that is negatively associated with budgetary increases is comprised of divorced but not remarried secretaries.

Undoubtedly the most interesting finding in the counterintuitive section is the law career variable (see Figure 1). Whether male or female, Cabinet secretaries with law backgrounds receive less funding than those without a legal career. Given that the 
number of lawyers in the Cabinet over time has sustained itself at about $35 \%$ of the population, this indicates systematic discrimination in the federal budget process against lawyers. Either Congress and the presidency perceives these individuals as incompetent or ineffective lobbyists for their departments, or these secretaries do not view increased levels of budgetary expenditures as a benchmark of success, or these lawyer-secretaries are disproportionately placed into departments in which the administration does not view as a priority. Interestingly, Figure 1 shows that women without legal backgrounds are more likely to be nominated to departments with substantial budgetary authority compared to male secretaries without a legal background.

Also noteworthy is the partisan nature regarding in which departments female secretaries are placed. Republican presidents consistently place female secretaries in smaller departments in terms of budgetary capacity compared to their male Cabinet counterparts. Conversely, Democratic presidents place women in a more diverse set of departments, as indicated by the wide confidence intervals for female secretaries nominated by Democratic presidencies (see Figure 2). However, there is no similar pattern when examining the variable displaying control of Congress; Democraticcontrolled Congresses are not substantially more likely to place female secretaries in a diverse selection of Cabinets than non-Democratic Congresses (see Figure 3). Another possible explanation for the relatively large confidence intervals in these plots may simply be attributed to the smaller population of women in the study; extending this study further into the past or the future may narrow the range of the budget expenditures of female secretaries. ${ }^{28}$ The two reported categories of marital status were both significant

\footnotetext{
${ }^{28}$ Female secretaries account for $14 \%$ of the study but have constituted $25 \%$ of all secretaries nominated since 1992. Were this trend to hold, by 2016 we would expect to have 16-20 more case-years of
} 
and associated positively with the growth of the annual budget, suggesting that the remaining category, those secretaries divorced but not remarried, had smaller budgetary expenditures. Figure 4 confirms that trend, showing that those secretaries who were divorced were more likely to see smaller annual budget levels.

The final category, which contains what I label the contingent variables, includes the measures of sex, partisanship, proportion of women in Congress, and Senate confirmation votes. These measures are only statistically significant depending upon the insertion of time counters, the narrower slice of time from 1986-2011 and the accompanying variable for House confirmation votes, or a combination of both.

Each measure of sex is contingent upon the presence of variables that account for time. It would appear that whenever the measure of sex by individual identity is significant and negative, the measure of sex by administration or Cabinet fails to achieve statistical significance. When the measure of sex by Cabinet is significant, however, it is positive. Finally, the measure of sex by the number of women in each department is significant in every model except the original 1962-2011 variant, but its directionality is contingent. The possible causes of these discrepancies will be discussed at length in the concluding chapter.

The other major section of contingent variables deals with the demographic and partisan composition of Congress and the presidency. Republican control of the legislature is hardly ever significant, but Democratic control of Congress or the variable accounting for partisan control of the presidency is only significant in the initial model

departments led by women. This would reduce the size of confidence intervals substantially by adding nearly $17 \%$ more new cases, many of which would fall near the mean budgetary-outlays value on a distribution curve. $95 \%$ of the cases with a female secretary would thus fall in a smaller range, and providing more predictive and explanatory power to these plots. 
and the time counter dummy variant, and even then the statistical significance of the variable for Democratic control of Congress is dependent on which measure of sex is employed. In the initial model, there is a significant and positive association between the number of women, but the interval time counter reverses that relationship to produce a negative association. Further study of the interaction between these contingent variables and time is necessary.

As for the time counters, there are benefits and disadvantages of each. The assumption that led to the creation of the dummy time counter is also an assumption that assumes that gender norms and hyperpartisanship remained constant before 1992, and from 1992 onward changed entirely. 1992, internationally known as the 'Year of the Woman', was characterized by the successful election of many women to the House of Representatives and the Senate. Gender norms could shift quickly as a result of generational replacement or a surge in the number of interested and available female candidates. Verifying this trend, the number of women in Congress, 1992 marks a very visible alteration that has characterized the last twenty years in Washington. Moreover, the change in Senate confirmation voting behavior changes remarkably in 1992 as well; nominees are less likely to receive voice votes, unanimous-consent votes, or even 100-0 recorded votes as the opposing party has used confirmation votes in a much more political manner. However, the dummy variable does not account for more subtle changes in gender norms and the shift to hyperpartisanship; hence I created the interval time counter to predict those changes. At the same time, changes in partisan behavior are not steady, and tend to occur after elections or major events. As such neither time 
counter should be favored over the other, nor should either counter be perceived as perfectly explanatory. Rather, the time counters give us two alternatives to consider.

The results section was framed to explain the bivariate and multivariate analysis performed on the dataset. This analysis dissects one example of how male privilege would manifest itself in the public sphere in a way that tries to account for the major processes in the federal government. In doing so I hope I have let the data tell a story about how the budget process works and how gender may influence the constituentrepresentative relationship that dictates the relative annual growth of departmental budgets. The concluding chapter will take these findings and define them in the context of a larger meaning that maintains relevance in political science literature. 


\section{CHAPTER FIVE CONCLUSIONS}

From the onset, I sought to determine whether or not women in the US Cabinet are discriminated against, through pervasive and ubiquitous male privilege. Manifestations of such privilege would materialize through tokenism, descriptive representation, and budgetary limitations upon women. The results show a more nuanced picture of gender in the US Cabinet and the budget process. While I do not rule out the possibility of male privilege and pervasive gender discrimination, the data do not bear out indicators of an institution hostile to female elites, but rather one that still relies on superficial qualities to determine worth.

The most obvious conclusion is that the predictive power of my model is such that between $50-60 \%$ of the variance in budgetary outlays spending is explained by the series of predictor variables, drawn from theory on the nature of the budget process and the role gender plays in this particular representative-constituency model. Explanatory studies of the budget process are an arduous undertaking and the notion that seventeen predictor variables can account for even half of such an elusively complicated annual government ritual bodes well for the future of analysis on the budget. There is likely no shortage of fixes and revisions to this model to better match the theoretical assumptions, but its predictive power should not be understated. Further analysis could include variables accounting for major political events, lobbying efforts from interest groups anticipating 
major legislation, or other personal characteristics such as race. Variables may also be omitted or revised, such as the variables for marital status. However, the core of this model would remain intact; Congress and the presidency grant budgetary increases to departments of the Cabinet based in part on superficial attributes of the individuals who run those agencies.

How does this study answer the fundamental question about gender discrimination? The results provide some evidence that male privilege may not be a pervasive, ubiquitous force in the American public sector. Among three measures of sex throughout twelve OLS regression models, none were consistently significant and negatively associated with the growth of annual budgets. In fact, under the measure of sex that accounted for the number of women in each administration, an increase in the number of female secretaries was positively associated with budget growth, which suggests that gender discrimination in this realm may not happen in the Cabinet. Other indicators in these models set up to indicate gender discrimination, such as marital status and career path, similarly show a lack of consistently negative relationships with budgetary increases. The natural inclination is thus to conclude that pervasive gender discrimination does not occur in the US Cabinet and federal budget process. As it stands, current female representation in the US Cabinet exceeds that of every other branch of the federal government, placing female elites in charge of vast sums of money and access to enormous political power.

Discrimination against policy generalists and descriptive representatives seems not to materialize given the high levels of education and government experience from Cabinet members. Female secretaries are more educated and have similar levels of prior 
government experience before nomination to the Cabinet compared to male secretaries. When combined with results that show the positive relationships between postbaccalaureate education or prior government experience and budgetary outlays increases, I conclude that women are being treated as policy specialists and substantive representatives for their experience and expertise. This should be considered a tentative conclusion since the study does not explicitly look to see if female Cabinet secretaries are being nominated to departments that match their career paths. ${ }^{29}$ However, the main point of a postgraduate degree is to acquire specialized expertise in a narrow field; it is unlikely a figure as scrutinized as the president would be able to nominate qualified nominees to the wrong parts of the Cabinet.

Certainly, this study should provide evidence that tokenism is not present in the US Cabinet. With the exception of holdouts in the Departments of Defense, Veterans' Affairs, and Treasury, the glass ceiling for each Cabinet department has been broken. Most importantly, if female secretaries were merely appointed as tokens, they would not be perceived as worthy of funding. The lack of consistent negative relationships does not bear out this expectation. Nor does this study show any clear indicator that a critical mass of female secretaries is reshaping expectations and roles of those government institutions. Were that to be the case, I would expect that the measure of sex by department would be positively associated with budgetary increases. The negative relationship actually reported between the measure of sex by department and budgetary outlays would suggest instead that there is still some resistance to departments typecast as feminine.

\footnotetext{
${ }^{29}$ Doing so would open the study up to criticism of subjectivity. What career fields do and do not adequately prepare a public official for service in the HUD, Commerce, Interior, or Energy departments?
} 
The finding concerning marital status of Cabinet secretaries was particularly interesting given that secretaries who had never married were positively associated with increases in their annual budget, even when accounting for inflation and the passage of time. Shifting societal norms on the desirability of the nuclear family, coupled with the entrance of millions of women into previously males-only careers in the past 40 years, has enabled a system that appears not to discriminate against professional, 'career-first' women. While remote, this finding could signal the emergence of female privilege, wherein society rewards women for certain attributes in the same vein that male privilege theory details societal benefits for men.

However, that conclusion should be tempered by noting that women who have been appointed to the Cabinet have largely tended to mimic their male colleagues' career paths rather than establish a contrasting career pipeline. Sixty percent of the male Cabinet secretaries and $46 \%$ of the female Cabinet secretaries in the study chose either law or business careers. Seventy-seven percent of all male secretaries and $93 \%$ of all female secretaries in the study had post-baccalaureate degrees. Most of the women in the Cabinet would not be labeled as radical by a large segment of the population, suggesting that they fit within a range of acceptable candidates for office. Some feminist scholars would consider that these female elites uphold the status quo, are 'conservative women', or conform to existing gender norms in order to seek advancement (hooks 1984, Ferguson 1984).

Furthermore, the results do show gender discrimination against women in several variants of the model. The measures of sex by individual identity and by department both show that being female is negatively associated with the growth of that secretary's budget 
in some circumstances. This should not be understated; the gender of a Cabinet secretary is related to how much money that secretary's department will earn for the upcoming fiscal year. Male privilege may not be the theory or paradigm that explains this behavior, yet this study lends credence to the broader literature that addresses gender inequality.

While the three measures of sex in the Cabinet report somewhat contradictory results, when one measure of sex is expressed as a vote of confidence, some patterns emerge. The measure of sex by administration is positively associated with increased budgetary outlays, suggesting that presidents who have more female secretaries are rewarded with an increase in budget size. This might indicate that gender diversity in Washington is praised and valued. However, it is the president, and not the Cabinet secretary, who is valued for promoting qualified women to the Cabinet, as the other two measures of sex indicate.

On a broader scope, this study indicates that politics still rest on superficial qualities rather than substantive policy. Competence of a public official is assessed by constituents, in part, by how that public official looks rather than how successfully they acquire and manage funding for government programs and services. In some cases, personal attributes are all that senators have to work with; many incoming secretaries are career politicians who have never managed a budget or do not possess managerial experience. Members of Congress themselves may not recognize a competent Cabinet nominee because of their own lack of managerial and executive-branch experience.

The pipeline model for explaining career advancement of elected public officials also appears to be a poor fit for the Cabinet. In this model, valuing competence comes into stark contrast with other attributes, such as having a law or business career. 
Recruiters at the local level may find that lawyers make good candidates, but their governing skills are found wanting once they enter the executive branch. Moreover, the low impact of prior government experience suggests that the pipeline process of State Legislature $\rightarrow$ Congress $\rightarrow$ Cabinet may not be the most efficient mechanism for vetting qualified candidates for service at the federal level. Perhaps instead of rejecting pipeline theory, a distinction needs to be drawn between describing elected and appointed officials. Appointed officials appear to be judged less on their superficial qualities and more on their political and policy skills.

Expansion of this type of analysis beyond the federal Cabinet and into state-level Cabinets as well as the executive branch leadership of other presidential systems would be the next logical step, in order to test the utility of this model and its generalizability. As it stands this model is only applicable to the United States federal government, due to assumptions about the nature of the budget process and the relationship between Cabinet officials, the president, and Congress. It would require substantial changes in order to become more generalizable; a reconfiguration of the dependent variable to a proportion of GDP, consideration for parliamentary systems, unicameral versus bicameral legislatures, the number of political parties and new conceptualizations of partisanship would all have to be taken into account to initiate a comparative study.

A legitimate criticism of this study is the lack of any explicit causal direction. Either nominations precede budget cuts or budget cuts precede nominations, but this study does not address which comes first. The only explicit example of gender discrimination following an expected causal mechanism is the negative association between female secretaries and Senate confirmation votes. An upcoming presidential 
election would easily test the utility of this model and answer causality questions, especially if the Republican nominee proves victorious in the general election. The growing voting gender gap favoring Democrats and the recent legislative controversy over abortion rights and contraceptive rights could result in a reduction in the number of female Cabinet members under a Republican presidency. At the same time, the US government has voted upon and is planning to carry out major cuts to its budget beginning in 2013. If the next president nominates women to departments scheduled to feel the brunt of these cuts, or places a reduced number of women in control of a substantially smaller portion of the federal budget, it would lend evidence to the usefulness of this model in predicting changes in the budget.

Another method to test causality would be to create an experiment that would closely mirror assumptions of the behavior of the primary actors in the budget process as well as roughly replicating the personal and professional characteristics of simulated Cabinet secretaries. Nor would it be difficult to set up a constituent-representative model for the experiment, given that the original intent of such a model was to examine voter behavior.

In-depth interviews with primary actors in the budget process could also solve the causality puzzle, although there may be difficulties with honesty and reliability from likely interviewees. Female members of the Cabinet may have a very different story to tell than male Appropriations Committee members. Nevertheless, such interviews would provide a level of breadth to this study; members of the Cabinet would shed light on parts of the budget process beyond the purview of public records, as well as illuminate what happens during the budget request submissions from the Cabinet to the OMB. 
Further research is required to answer questions and resolve the imperfections of this study. Yet it has gone a step beyond much of the existing literature that analyzed female representation in the Cabinet or budgetary policy in descriptive terms. It may even provide a starting point for future analysis of public-servant competence in other spheres of government. The results question assumptions about the nature of male privilege and gender inequity, and hopefully will contribute to the growing literature of women in politics. 


\section{TABLES AND FIGURES}

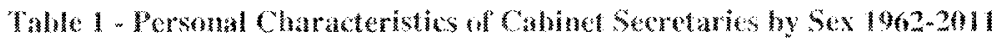

\begin{tabular}{|lllllllll|}
\hline & $\begin{array}{l}\text { Postgraduate } \\
\text { Degree }\end{array}$ & $\begin{array}{l}\text { Business } \\
\text { Career }\end{array}$ & $\begin{array}{l}\text { Law } \\
\text { Career }\end{array}$ & $\begin{array}{l}\text { Divorced, } \\
\text { not } \\
\text { Remarried }\end{array}$ & $\begin{array}{l}\text { Never } \\
\text { Married }\end{array}$ & $\begin{array}{l}\text { Democratic } \\
\text { Presidency }\end{array}$ & $\begin{array}{l}\text { Democratic } \\
\text { Congress }\end{array}$ & $\begin{array}{l}\text { 10 Years } \\
\text { Government } \\
\text { Experience }\end{array}$ \\
\hline \%Male & 77.2 & 25.5 & 35.4 & 2.2 & 1.5 & 41.4 & 61.5 & 37.2 \\
\%Female & 93.4 & 8.8 & 36.3 & 5.5 & 34.1 & 52.7 & 42.9 & 31.9 \\
$\%$ All & 79.5 & 23.2 & 35.5 & 2.7 & 6.1 & 43.0 & 58.8 & 36.5 \\
${ }^{2}$ & 12.593 & 12.312 & .025 & 3.291 & 144.779 & 4.082 & 11.195 & .967 \\
$\mathrm{p} \leq$ & .000 & .000 & .874 & .070 & .000 & .043 & .001 & .325 \\
\hline
\end{tabular}

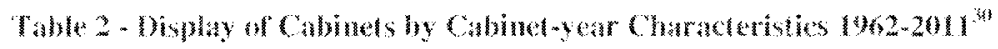

\begin{tabular}{|llllllll|}
\hline & Male & Female & $\begin{array}{l}\text { Postgrad } \\
\text { Degree }\end{array}$ & $\begin{array}{l}\text { Business } \\
\text { Career }\end{array}$ & $\begin{array}{l}\text { Law } \\
\text { Career }\end{array}$ & $\begin{array}{l}\text { Never } \\
\text { Married }\end{array}$ \\
\hline State & 39 & 11 & 46 & 0 & 20 & 4 & 50 \\
Justice & 42 & 8 & 50 & 0 & 45 & 8 & 50 \\
Agriculture & 45 & 5 & 32 & 14 & 29 & 0 & 50 \\
Interior & 46 & 4 & 36 & 12 & 12 & 4 & 50 \\
Commerce & 46 & 4 & 24 & 31 & 12 & 1 & 50 \\
Labor & 30 & 20 & 37 & 18 & 5 & 8 & 50 \\
HHS & 35 & 15 & 44 & 6 & 17 & 8 & 50 \\
HUD & 42 & 5 & 42 & 9 & 19 & 0 & 47 \\
Transportation & 38 & 7 & 32 & 6 & 14 & 0 & 45 \\
Energy & 31 & 4 & 34 & 5 & 16 & 0 & 35 \\
Education & 27 & 5 & 25 & 0 & 9 & 0 & 32 \\
Homeland & 4 & 3 & 7 & 0 & 7 & 3 & 7 \\
Security & & & & & & & \\
Defense & 50 & 0 & 48 & 10 & 6 & 0 & 50 \\
Veterans' Affairs & 23 & 0 & 14 & 0 & 6 & 0 & 23 \\
Treasury & 50 & 0 & 37 & 37 & 10 & 3 & 50 \\
\hline Total & 548 & 91 & 508 & 148 & 227 & 39 & 639 \\
\hline
\end{tabular}

${ }^{30}$ Cabinet-years refer to each case; as an example, the Commerce department in 1973 would be a Cabinetyear, the Commerce Department in 1974 would be a different Cabinet-year, as would the Interior Department in 1973. 
Table 3-Percentage of Cabinet Secretares with Pesonal Characteristics by Administration, 1962-2011

\begin{tabular}{|llllll|}
\hline & Female & Law Career & $\begin{array}{l}\text { Business } \\
\text { Career }\end{array}$ & $\begin{array}{l}\text { Secretary } \\
\text { Never Married }\end{array}$ & $\begin{array}{l}\text { Postgraduate } \\
\text { Degree }\end{array}$ \\
\hline JFK & .00 & .50 & .33 & .00 & .78 \\
LBJ & .00 & .51 & .16 & .02 & .92 \\
Nixon & .00 & .24 & .41 & .00 & .59 \\
Ford & .09 & .36 & .18 & .00 & .77 \\
Carter & .16 & .43 & .10 & .14 & .82 \\
Reagan & .09 & .30 & .30 & .00 & .71 \\
HWB & .09 & .18 & .23 & .00 & .73 \\
Clinton & .25 & .50 & .05 & .18 & .96 \\
GWB & .23 & .27 & .39 & .07 & .78 \\
Obama & .27 & .42 & .07 & .07 & .87 \\
\hline Total & .14 & .355 & .23 & .06 & .80 \\
\hline
\end{tabular}

*Democratic administrations bolded and italicized

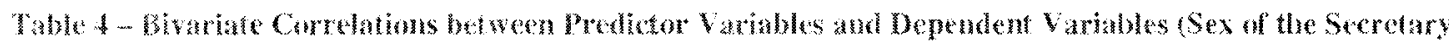
and Indiget Ou(tays)

\begin{tabular}{|l|l|l|}
\hline & $\begin{array}{l}\text { Correlation with Sex of } \\
\text { Secretary }\end{array}$ & $\begin{array}{l}\text { Correlation with Budget } \\
\text { Outlays }\end{array}$ \\
\hline Sex of Secretary & - & $.130^{* *}$ \\
\hline Postgraduate Education & $.140^{* *}$ & $.096^{*}$ \\
\hline Prior Government Experience & -.010 & $.210^{* *}$ \\
\hline Business Career & $-.139^{* *}$ & .047 \\
\hline Law Career & .006 & $-.226^{* *}$ \\
\hline $\begin{array}{l}\text { Secretary } \\
\text { Married/Remarried/Widowed }\end{array}$ & $-.444^{* *}$ & -.063 \\
\hline Secretary Never Married & $.476^{* *}$ & $.108^{* *}$ \\
\hline Number of Children & $-.398^{* *}$ & $-.166^{* *}$ \\
\hline Party of the President & $.080^{*}$ & -.048 \\
\hline Democratic Control of Congress & $-.132^{* *}$ & $-.275^{* *}$ \\
\hline Republican Control of Congress & $.159^{* *}$ & $.237^{* *}$ \\
\hline Number of Women in Congress & $.256^{* *}$ & $.508^{* *}$ \\
\hline Senate Confirmation Votes & $-.093^{*}$ & -.008 \\
\hline House Appropriations Votes\# & $-.127^{*}$ & -.065 \\
\hline
\end{tabular}

**Correlation significant at the .01 level

* Correlation significant at the .05 level

\#1986-2011 dataset only 
Thbo $5-$ Showing the Lffects of Personal Charateristics on Budget Expenditures. 1962m2011

\begin{tabular}{|c|c|c|c|c|c|c|}
\hline & $\begin{array}{c}\text { Sex by } \\
\text { Individual } \\
1962-2011\end{array}$ & $\begin{array}{c}\text { Sex by } \\
\text { Cabinet } \\
1962-2011\end{array}$ & $\begin{array}{c}\text { Sex by } \\
\text { Department } \\
1962-2011 \\
\end{array}$ & $\begin{array}{c}\text { Sex by } \\
\text { Individual } \\
1986-2011\end{array}$ & $\begin{array}{c}\text { Sex by } \\
\text { Cabinet } \\
1986-2011 \\
\end{array}$ & $\begin{array}{c}\text { Sex by } \\
\text { Department } \\
1986-2011\end{array}$ \\
\hline Constant & $2.829 * * *$ & $2.794 * * *$ & $2.796 * * *$ & $3.017 * * *$ & $2.820 * * *$ & $2.925 * * *$ \\
\hline Sex & -.115 & $.196 * * *$ & -.024 & $-.189 * *$ & -.057 & $-.053 * * *$ \\
\hline Postgrad Degree & $.287^{* * * *}$ & $.298 * * *$ & $.286^{* * *}$ & $.371 * * *$ & $.368 * * *$ & $.365 * * *$ \\
\hline Prior Gov't Experience & $.006 * *$ & $.008 * * *$ & $.006^{* *}$ & $.011 * * *$ & $.011 * * *$ & $.010^{* * *}$ \\
\hline Business Career & -.083 & -.030 & -.078 & -.061 & -.040 & -.058 \\
\hline Law Career & $-.372 * * *$ & $-.376^{* * *}$ & $-.376^{* * * *}$ & $-.394 * * *$ & $-.392 * * *$ & $-.407 * * *$ \\
\hline Married/Remarried/Widow & $.321 * *$ & $.370 * * *$ & $.341 * *$ & $.360 * * *$ & $.394 * * *$ & $.414^{* * *}$ \\
\hline Never Married & $.340 * *$ & $.290^{* *}$ & $.310^{*}$ & $.353 * * *$ & $.262 *$ & $.308 * *$ \\
\hline Number of Children & $-.026^{*}$ & -.020 & $-.024 *$ & $-.029 *$ & -.017 & -.024 \\
\hline Party of the President & $-.119 * *$ & $-.221 * * *$ & $-.117 * *$ & -.032 & .023 & -.024 \\
\hline $\begin{array}{l}\text { Democratic Control of } \\
\text { Congress }\end{array}$ & $-.146 * *$ & -.099 & $-.148 * *$ & .004 & .004 & -.003 \\
\hline $\begin{array}{l}\text { Republican Control of } \\
\text { Congress }\end{array}$ & -.102 & $-.132 *$ & -.103 & -.045 & -.022 & -.051 \\
\hline Women in Congress & $.012 * * *$ & .002 & $.012 * * *$ & $.006^{* * *}$ & $.008^{* *}$ & $.006 * * *$ \\
\hline Senate Confirmation Votes & $.005^{* *}$ & $.006^{* *}$ & $.005^{* *}$ & $.006 * * *$ & $.007 * *$ & $.007 * *$ \\
\hline $\begin{array}{l}\text { House Appropriation } \\
\text { Votes\# }\end{array}$ & - & - & - & .00002 & .000 & .00005 \\
\hline Inflation & $.035 * * *$ & $.022 * *$ & $.034 * * *$ & .003 & .001 & .002 \\
\hline Mandatory Expenditures & $.000003 * * *$ & $.000003 * * *$ & $.000003^{* * *}$ & $.000003 * * *$ & $.000003 * * *$ & $.000003 * * *$ \\
\hline Adjusted $\mathrm{R}^{2}$ & .480 & .500 & .480 & .508 & .501 & .513 \\
\hline
\end{tabular}

$* * *$ Significant at the .01 level

**Significant at the .05 level

* Significant at the .10 level

\#1986-2011 only

Ordinary-Least Squares Regression between predictor variables and dependent variable Budget Outlays 


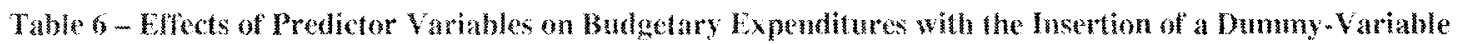
Time Cunter

\begin{tabular}{|l|c|c|c|}
\hline & $\begin{array}{c}\text { Sex by Individual } \\
1962-2011\end{array}$ & $\begin{array}{c}\text { Sex by Cabinet } \\
1962-2011\end{array}$ & $\begin{array}{c}\text { Sex by Department } \\
1962-2011\end{array}$ \\
\hline Constant & $3.485^{* * *}$ & $3.501^{* * *}$ & $3.515^{* * *}$ \\
\hline Sex & .071 & $.151^{* * *}$ & $.067^{* * *}$ \\
\hline Postgrad Degree & $.151^{* * *}$ & $.165^{* * *}$ & $.144^{* * *}$ \\
\hline Prior Gov't Experience & $.008^{* * *}$ & $.008^{* * *}$ & $.009^{* * *}$ \\
\hline Business Career & -.016 & .005 & .000 \\
\hline Law Career & $-.233^{* * *}$ & $-.242^{* * *}$ &. $.212^{* * *}$ \\
\hline Married/Remarried/Widow & $.194^{*}$ & $.212^{*}$ & .169 \\
\hline Never Married & $.350^{* *}$ & $.368^{* * *}$ & $.345^{* *}$ \\
\hline Number of Children & $-.024^{* *}$ & $-.026^{* *}$ & $-.020^{*}$ \\
\hline Party of the President & $-.093^{* *}$ & $-.179^{* * *}$ & $-.087^{* *}$ \\
\hline $\begin{array}{l}\text { Democratic Control of } \\
\text { Congress }\end{array}$ & $-.095^{*}$ & -.060 & $-.087^{*}$ \\
\hline $\begin{array}{l}\text { Republican Control of } \\
\text { Congress }\end{array}$ & -.070 & -.099 & -.060 \\
\hline Women in Congress & $.009^{* * *}$ & .002 & $.008^{* * *}$ \\
\hline Senate Confirmation Votes & -.002 & -.002 & -.003 \\
\hline House Appropriation Votes\# & - & - & - \\
\hline Inflation & $.027^{* * *}$ & $.017^{* *}$ & $.027^{* * *}$ \\
\hline Mandatory Expenditures & $.000003^{* * *}$ & $.000003^{* * *}$ & $.000003^{* * *}$ \\
\hline Time Counter (Dummy) & $.660^{* * *}$ & $.635^{* * *}$ & $.703^{* * *}$ \\
\hline Adjusted R & .632 & .643 & .639 \\
\hline
\end{tabular}

*** Significant at the .01 level

**Significant at the .05 level

*Significant at the .10 level

\#1986-2011 only

Ordinary-Least Squares Regression between predictor variables and dependent variable Budget Outlays 


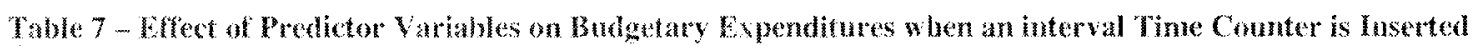

\begin{tabular}{|c|c|c|c|}
\hline & $\begin{array}{c}\text { Sex by Individual } \\
1962-2011\end{array}$ & $\begin{array}{l}\text { Sex by Cabinet 1962- } \\
2011\end{array}$ & $\begin{array}{c}\text { Sex by Department 1962- } \\
2011\end{array}$ \\
\hline Constant & $2.548 * * *$ & $2.522 * * *$ & $2.511 * * *$ \\
\hline Sex & $-.136^{*}$ & .054 & $-.034^{*}$ \\
\hline Postgrad Degree & $.295 * * *$ & $.297 * * *$ & $.294 * * *$ \\
\hline Prior Gov't Experience & $.006^{* *}$ & $.007 * *$ & $.006 * *$ \\
\hline Business Career & .006 & .023 & .011 \\
\hline Law Career & $-.354 * * *$ & $-.357 * * *$ & $-.360 * * *$ \\
\hline Married/Remarried/Widow & $.344 * * *$ & $.372 * * *$ & $.368 * * *$ \\
\hline Never Married & $.346 * *$ & $.294 *$ & $.314 * *$ \\
\hline Number of Children & $-.028 * *$ & $-.022 *$ & $-.026 * *$ \\
\hline Party of the President & .026 & -.013 & .029 \\
\hline $\begin{array}{l}\text { Democratic Control of } \\
\text { Congress }\end{array}$ & -.056 & -.052 & -.057 \\
\hline $\begin{array}{l}\text { Republican Control of } \\
\text { Congress }\end{array}$ & -.060 & -.069 & -.061 \\
\hline Women in Congress & $-.009 * * *$ & $-.010^{* * *}$ & $-.009 * * *$ \\
\hline Senate Confirmation Votes & $.005^{* *}$ & $.005^{* *}$ & $.005 * *$ \\
\hline $\begin{array}{l}\text { House Appropriation } \\
\text { Votes\# }\end{array}$ & - & - & - \\
\hline Inflation & .014 & .012 & .013 \\
\hline Mandatory Expenditures & $.000003 * * *$ & $.000003^{* * *}$ & $.000003 * * *$ \\
\hline Time Counter (Interval) & $.042 * * *$ & $.038 * * *$ & $.042 * * *$ \\
\hline Adjusted $\mathrm{R}^{2}$ & .530 & .529 & .530 \\
\hline
\end{tabular}

$* * *$ Significant at the .01 level

$* *$ Significant at the .05 level

*Significant at the .10 level

\#1986-2011 only

Ordinary-Least Squares Regression between predictor variables and dependent variable Budget Outlays

Table - Measures of Sex for MII Variants of the Mutivatiate Model

\begin{tabular}{|l|c|c|c|}
\hline & Sex by Individual & Sex by Cabinet & $\begin{array}{c}\text { Sex by } \\
\text { Department }\end{array}$ \\
\hline Original 1962-2011 & -.115 & $.196^{* * *}$ & -.024 \\
\hline Original 1986-2011 & $-.189^{* *}$ & -.057 & $-.053^{* * *}$ \\
\hline Time Counter (Dummy) & .071 & $.151^{* * *}$ & $.067^{* * *}$ \\
\hline Time Counter (Interval) & $-.136^{*}$ & .054 & $-.034^{*}$ \\
\hline
\end{tabular}

***Significant at the .01 level

** Significant at the .05 level

*Significant at the .10 level 
Figure 1 - Gender by Law Degree

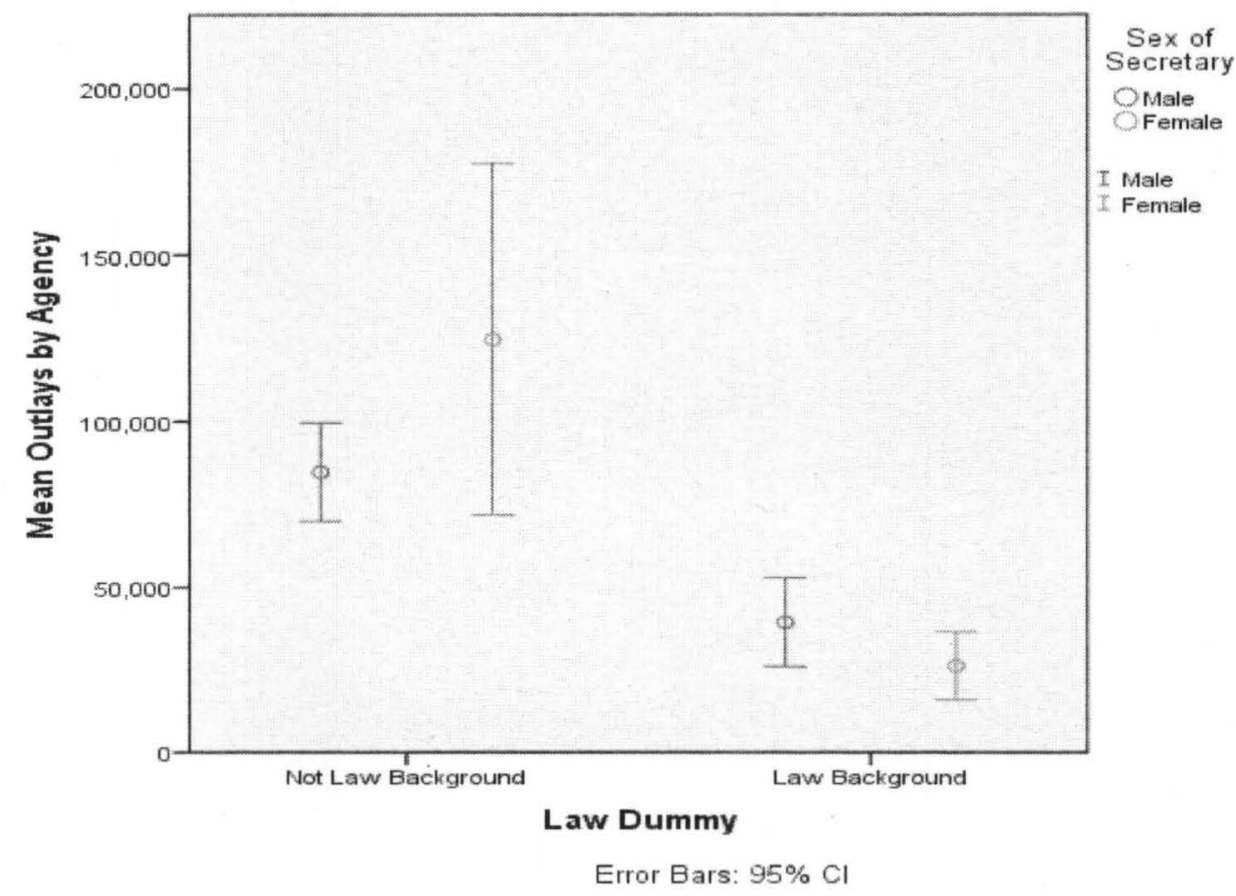

Figure 2 - Gender by Party of the President

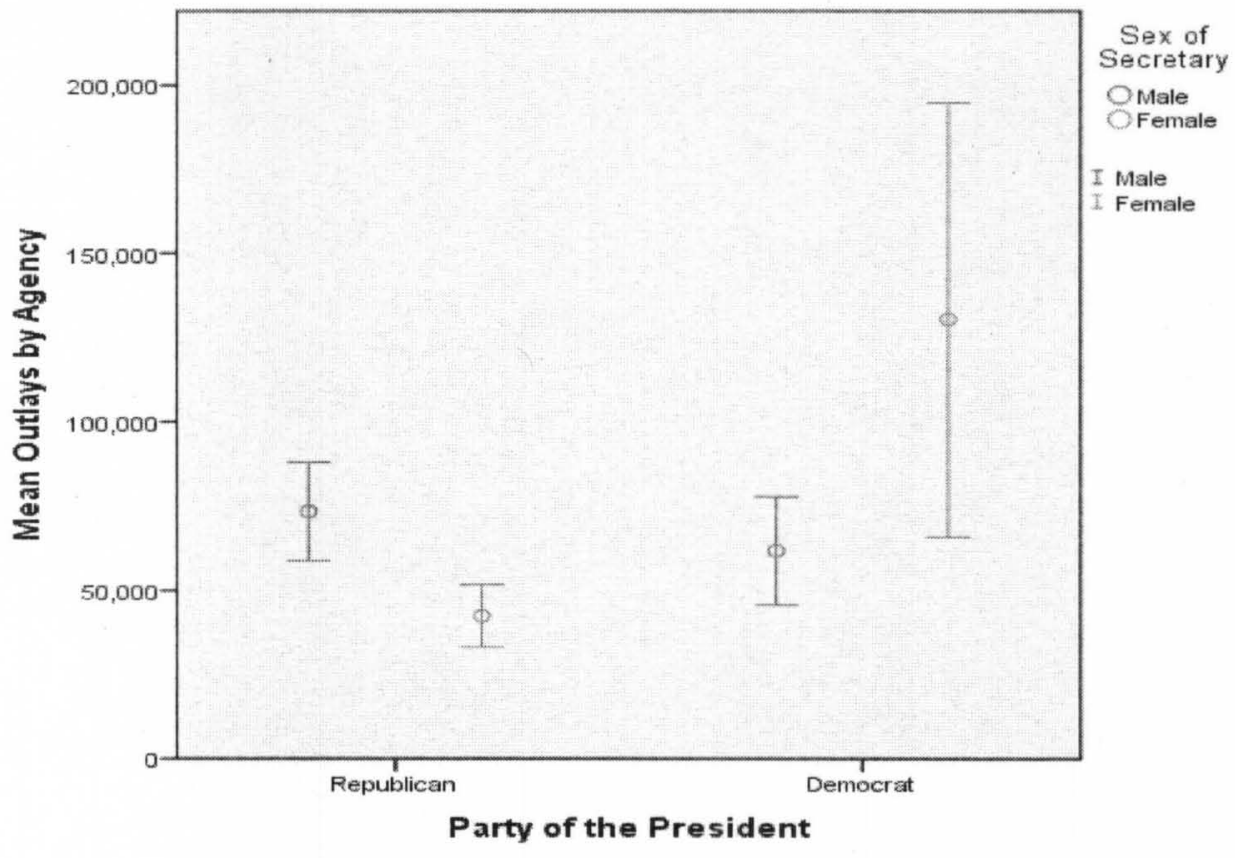

Error Bars: $95 \% \mathrm{Cl}$ 
Figure 3 - Gender by Democratic Control of Congress

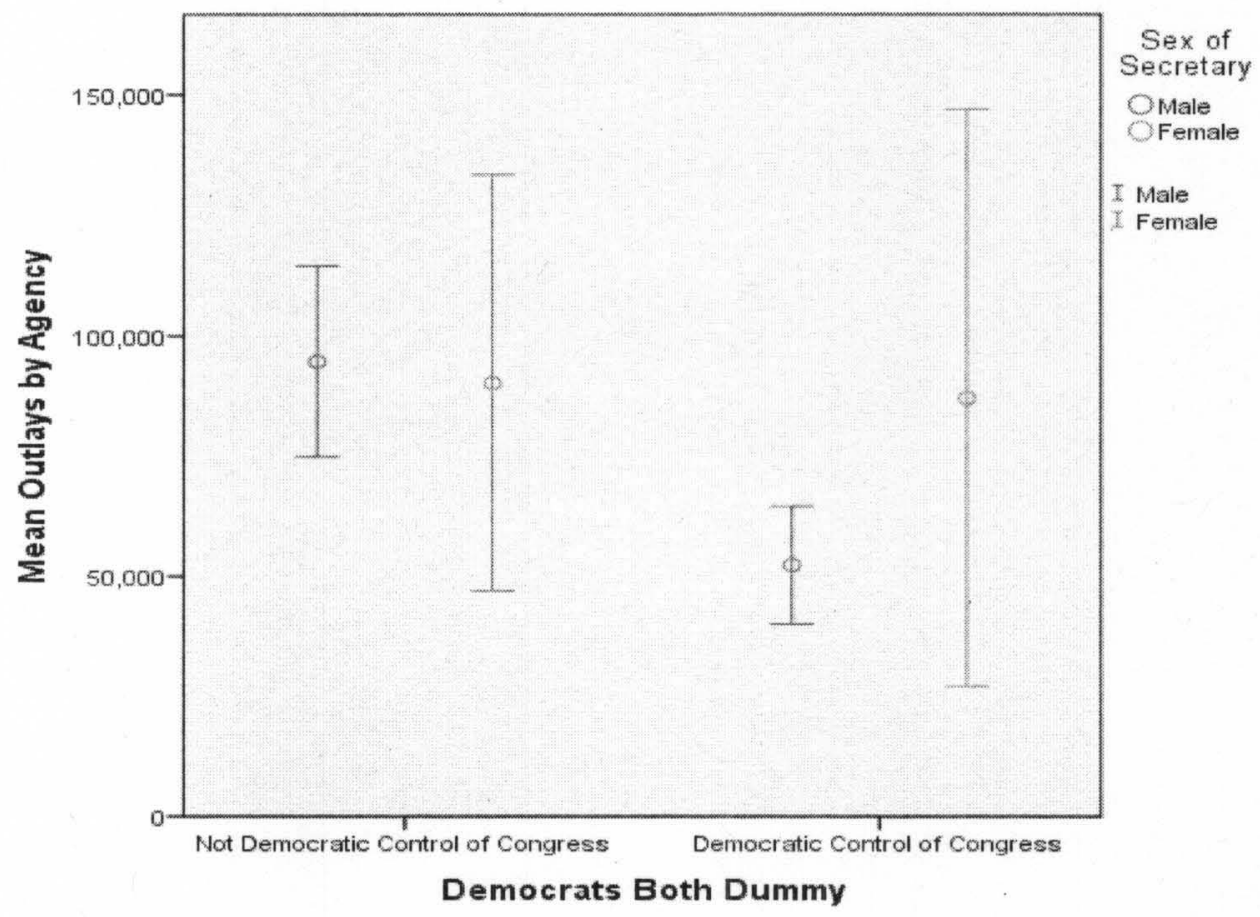

Error Bars: $95 \% \mathrm{Cl}$

Rigure 4 - Gender by Marital Status (Diworced)

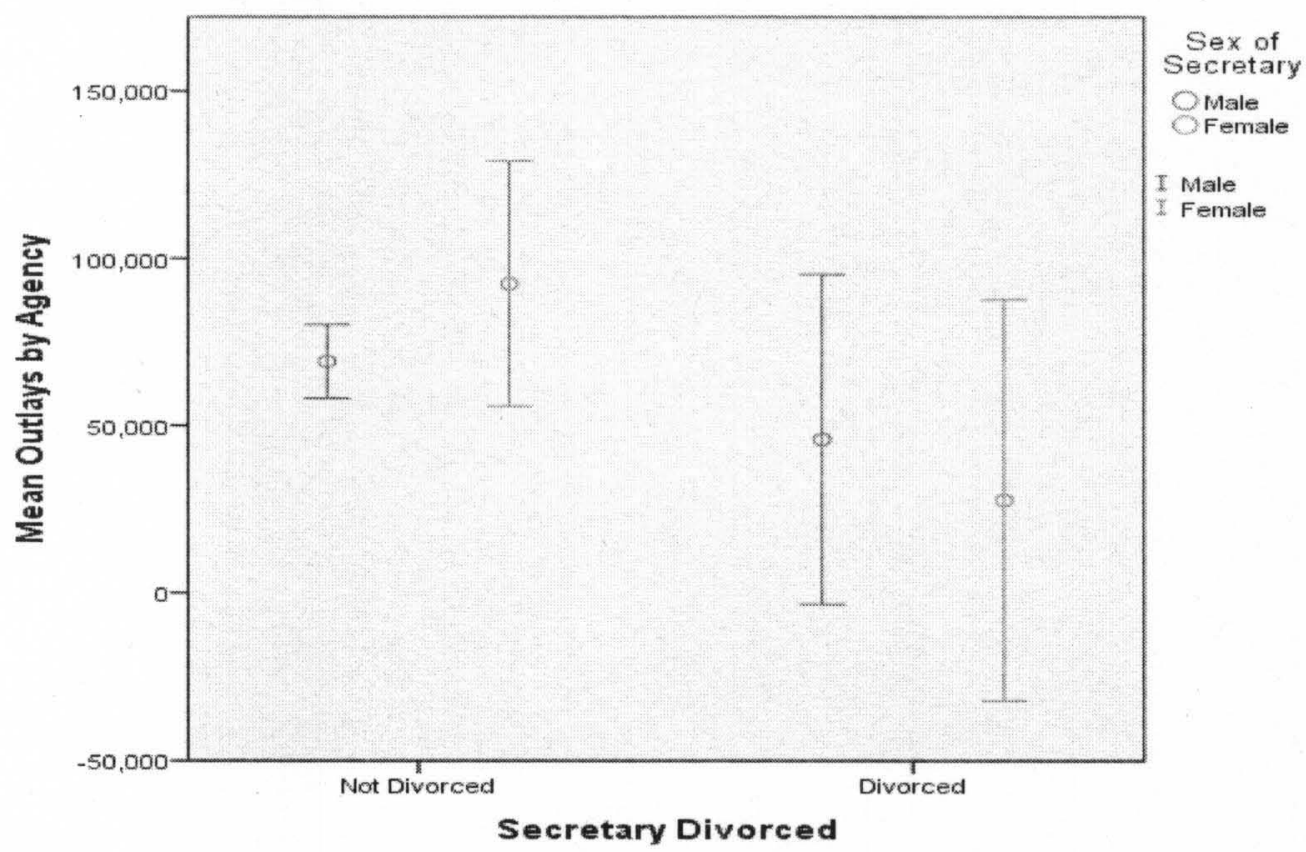

Error Bars: $95 \% \mathrm{cl}$ 


\section{REFERENCES}

Acker, Joan. 1990. "Hierarchies, Jobs, Bodies: A Theory of Gendered Organizations." Gender and Society 4(2):139-158.

Ackerly, Brooke. 2009. "Why a Feminist Theorist Studies Methods." Politics \& Gender 5(3), 431-436.

Alexander, Deborah; Andersen, Kristi. 1993. "Gender as a Factor in the Attribution of Leadership Traits." Political Research Quarterly 46(3): 527-545.

Apodaca, Clair. 2009. "Overcoming Obstacles in Quantitative Feminist Research." Politics \& Gender 5(3), 419-426.

Barakso, Maryann. 2007. "Is There a 'Woman's Way' of Governing? Assessing the Organizational Structures of Women's Membership Associations." Politics \& Gender 3(2):201-227.

Benjamin, Georges C. 2001. "Federal Budget Helps Drive Health Policy." Physician Executive July 01, 2001.

BLS.Gov. 2011. "Consumer Price Index." http://www.bls.gov/cpi/home.htm. Accessed April 20, 2011.

Bobbitt-Zeher, Donna. 2007. "The Gender Income Gap and the Role of Education." Sociology of Education 80, 1, 1-22.

Bogoch, Bryna. 1997. "Gendered Lawyering: Difference and Dominance in LawyerClient Interaction." Law \& Society Review 31(4): 677-712.

Borelli, MaryAnne. 2002. The President's Cabinet: Gender, Power, and Representation. L. Rienner Publishers, Boulder, CO.

Borelli, MaryAnne; Martin, Janet M. 1997. The Other Elites: Women, Politics, and Power in the Executive Branch. Boulder: Lynne Rienner Publishers, Inc.

Borie-Holtz, Debra Ann. 2011. "Breaking Through the Glass Ceiling: Only to [G]et Stuck in the Rafters: A Study of Gendered Legislative Leadership in the 50 states." Thesis $(P h D)$ Rutgers University. 
Bowling, Cynthia J. 2006. "Cracked Ceilings, Firmer Floors, and Weakening Walls: Trends and Patterns in Gender Representation Among Executives Leading American State Agencies, 1970-2000." Public Administration Review 66(6):823836.

Cogan, John F.; Muris, Timothy J.; Schick, Allen. 1994. The Budget Puzzle: Understanding Federal Spending. Stanford University Press, CA.

Conover, Pamela Johnston. 1988. "Feminists and the Gender Gap." The Journal of Politics 50(4):985-1010.

CQ Staff Press. Federal Staff Directory. 2006-2010. Congressional Quarterly Press, USA.

Davis, Sue; Haire, Susan; Songer, Donald. 1993. "Voting-Behavior and Gender on the United States Courts of Appeals." Judicature 77(3): 129-133.

Dolan, Julie. 2001. "Political Appointees in the United States: Does Gender Make a Difference?" Political Science \& Politics 34(2):213-216.

Dolan, Julie. 2002. "Representative Bureaucracy in the Federal Executive: Gender and Spending Priorities." Journal of Public Administration Research and Theory: JPart 12(3):353-375

Dull, Matthew; Roberts, Patrick S. 2009. "Continuity, Competence, and the Succession of Senate-Confirmed Agency Appointees, 1989-2009." Presidential Studies Quarterly 39(3):432-453.

Escobar-Lemmon, Maria; Taylor-Robinson, Michele M. 2009. "Getting to the Top: Career Paths of Women in Latin American Cabinets." Political Research Quarterly 62(4):685-699.

Equal Employment Opportunity Commission. Sex-Based Discrimination. October 06, 2011. http://www.eeoc.gov/laws/types/sex.cfm

Ferber, Abby L.; Herrera, Andrea O'Reilly; Samuels, Dena R. 2007. "The Matrix of Oppression and Privilege: Theory and Practice for the New Millennium." American Behavioral Scientist 51(4):516-531.

Ferguson, Kathy E. 1984. The Feminist Case Against Bureaucracy. Temple University Press, Philadelphia PA.

Fox, Richard L.; Lawless, Jennifer. 2010. "If Only They'd Ask: Gender, Recruitment, and Political Ambition." The Journal of Politics 72(2):310-326 
Fox, Richard L; Oxley, Zoe M. 2003. "Gender Stereotyping in State Executive Elections: Candidate Selection and Success." The Journal of Politics 65(3): 833-850

Gose, Ben. 2004. "Charities Pay Women Less Than Men, Study Finds," Chronicle of Philanthropy 17(3):40.

GPOAccess.Gov. 2011. "Budget Outlays 1962-2014.” http://www.gpoaccess.gov/usbudget/fy10/hist.html. Accessed April 20, 2011.

Greed, Clara. 2000. "Women in the Construction Professions: Achieving Critical Mass." Gender, Work and Organization 7(3):2000.

Grey, Sandra. 2006. "Numbers and Beyond: The Relevance of Critical ${ }_{1}$ Mass in Gender Research." Politics \& Gender 2(4), 492-502.

Hogan, Robert E. 2001. "The Influence of State and District Conditions on the Representation of Women in US State Legislatures." American Politics Research 29(1):4-24.

Hooks, B. 1984. Feminist theory from margin to center. Boston, MA, South End Press.

Howell, Susan E; Day, Christine L. 2000. "Complexities of the Gender Gap." The Journal of Politics 62(3):858-874.

Huddy, L; Terkildsen, N. 1993. "Gender Stereotypes and the Perception of Male and Female Candidates." American Journal of Political Science 37(1):119-147.

Jalalzai, Farida; Krook, Mona. 2010. "Beyond Hillary and Benazir: Women's Political Leadership Worldwide." International Political Science Review 31(1):5-21.

Justice.gov. The Attorney General. http://www.justice.gov/ag/. Accessed on 12/6/2011.

Kahn, Kim Fridkin. 1994. "The Distorted Mirror: Press Coverage of Women Candidates for Statewide Office." The Journal of Politics 56(1): 154-173.

Kastellac, Jonathan P.; Lax, Jeffrey R.; Phillips, Justin H. 2010. "Public Opinion and Senate Confirmation of Supreme Court Nominees." The Journal of Politics 72(3): 767-784.

Kellstedt, Paul M.; Peterson, David A; Ramirez, Mark D. 2010. "The Macro Politics of a Gender Gap." Public Opinion Quarterly 74(3):477-498.

King, James D.; Riddlesberger Jr., James W. 1991. "Senate Confirmation of Appointments to the Cabinet and Executive Office of the President." The Social Science Journal 28(2): 189-202. 
Levine, Kenneth. 2005. "Voter Decision Making: The Tensions of Personal Identity, Personal Ethics, and Personal Benefit." American Behavioral Scientist 49(1):6377.

Manning, Jennifer; Shogan, Colleen J. Congressional Research Service. 2011. Women in the United States Congress, 1917-2011. http://www.fas.org/sgp/crs/misc/RL30261.pdf

Mariani, Mack D. 2008. "A Gendered Pipeline? The Advancement of State Legislators to Congress in Five States." Politics \& Gender 4(2):285-308.

Martin, Janet M. 1991. "An Examination of Executive Branch Appointments in the Reagan Administration By Background and Gender." The Western Political Quarterly 44(1).

McDonagh, Eileen. 2010. "It Takes a State: A Policy Feedback Model of Women's Political Representation." Perspectives on Politics 8(1):69-91.

Okimoto, Tyler; Brescoll, Victoria. 2010. "The Price of Power: Power Seeking and Backlash Against Female Politicians." Personality and Social Psychology Bulletin 36(7):923-936.

Parsons, Eileen Carlton. 2001. "Using Power and Caring to Mediate White Male Privilege, Equality, and Equity in an Urban Elementary Classroom; Implications for Teacher Preparation." The Urban Review 33(4):321-338.

Renzulli, Linda A.; Grant, Linda; Kathuria, Sheetija. 2006. "Race, Gender, and the Wage Gap: Comparing Faculty Salaries in Predominantly White and Historically Black Colleges and Universities." Gender \& Society 2006 20(4): 491-510.

Rich, Adrienne. 1993. Compulsory Heterosexuality and the Lesbian Experience. In "The Lesbian \& Gay Studies Reader," Abelove, Barale, Halperin, eds. NY: Routledge.

Rubin, Irene S. 1993. The Politics of Public Budgeting: Getting and Spending, Borrowing and Balancing. Chatham House Publishers, Chatham NJ.

Rule, Wilma. 1981. "Why Women Don't Run: The Critical Contextual Factors in Women's Legislative Recruitment.” The Western Political Quarterly 34(1):60-77.

Sanbonmatsu, Kira. 2002. "Political Parties and the Recruitment of Women to State Legislatures." The Journal of Politics 64(3): 791-809

Senate.gov. "Presidential Cabinet Nominations." 2011. http://www.senate.gov/reference/resources/pdf/cabinettable.pdf 
Shapiro, Robert Y; Mahajan, Harpreet. 1986. "Gender Differences in Policy Preferences: A Summary of Trends from the 1960s to the 1980s." The Public Opinion Quarterly 50(1):42-61.

Shomer, Yael. 2009. "Candidate Selection, Procedures, Seniority, and Vote-Seeking Behavior." Comparative Political Studies 42(7):945-970.

Sinclair, Barbara. 1997. Unorthodox Lawmaking. Congressional Quarterly Press, USA.

Sobel and Sicilia, eds. 2003. The United States Executive Branch, Volumes I and II. Greenwood Press, CT.

Stambough, Steven; O'Regan, Valerie. 2007. "Republican Lambs and the Democratic Pipeline: Partisan Differences in the Nomination of Female Gubernatorial Candidates." Politics \& Gender 3(3):349-368.

State.gov. The Secretary of State. http://www.state.gov/secretary/index.htm. Accessed on $12 / 6 / 2011$.

Stepick, Alex; Castro, Max; Grenier, Guillermo; Dunn, Marvin. 2003. This Land is Our Land: Immigrants and Power in Miami. University of California Press, USA.

Stimson, J. A. 1985. "Regression in Space and Time - A Statistical Essay." American Journal of Political Science. 29(4): 914-947.

Szmer, John J.; Sarver, Tammy A.; Kaheny, Erin B. 2010. "Have We Come a Long Way, Baby? The Influence of Attorney Gender on Supreme Court Decision Making." Politics \& Gender 6(1):1-36.

U.S. Senate. Senate.gov. 1986-2012. Legislation \& Records. Accessed February $5^{\text {th }}$, 2012.

http://www.senate.gov/pagelayout/legislative/b_three_sections_with_teasers/appr opsbills.htm

Vexler, Robert I. 1975. The Vice-Presidents and Cabinet Members. Oceana Publications, Inc. USA.

White House Press Release. January 26, 2011. President, Vice President, Members of the Cabinet Fan Out Across the Country. http://www2.counton2.com/membercenter/share-this/print/?content=ar1384270. Accessed on 12/6/2011.

Wilkins, Vicky M. 2007. "Exploring the Causal Story: Gender, Active Representation, and Bureaucratic Priorities." Journal of Public Administration Research and Theory 17(1):77-94. 


\section{CURRICULUM VITA}

Kevin Fahey

500 Sherburn Lane, \#A-4, Louisville KY 40207

yehafnivek@yahoo.com*740-513-7866

\section{Education}

University of Louisville, August 2010-May 2012

Current GPA: 3.94 .

Advisor: Dr. Laurie Rhodebeck

Ohio Wesleyan University, August 2006 - May 2010

Bachelor of Arts, cum Laude, University Honors

Majors: Political Science, International Studies

Advisor: Dr. Sean Kay

Delaware Hayes High School, August 2002 - June 2006

High School Diploma, with Honors

\section{$\underline{\text { Research }}$}

- The Budget Gap: Gender Inequality Amongst U.S. Cabinet Departments, 1962-2011: an examination of US Cabinet-level chiefs to determine whether there is a gender gap in the budget allocation for executive officials (20102012)

- The State and Direction of Asian Comparative Politics: Who What, Where, How?: a meta-analysis of seven East Asian comparative-politics journals to test whether the key conclusions of Munck \& Snyder's 2005 piece of comparative methodology and epistemology are still valid today (2010-2011)

- Scouting in Chile: an examination of the efficacy of the national Boy Scout organization of Chile; Establishing Cyber Scouting Activities, an exploration of the practicality of establishing multi-cultural virtual activities within the World Association of Scouting (2009)

- Scouting in Russia: an examination of the efficacy of the national Boy Scout organization of Russia; Establishing Cyber Scouting Activities, an exploration of the practicality of establishing multi-cultural virtual activities within the World Association of Scouting (2009)

- The Libertarian Party: an examination of the Libertarian Party from a structural and organizational standpoint as it has evolved over the past thirty years, including its grass-roots and intellectual development (2008)

\section{$\underline{\text { Presentations }}$}

- The Budget Gap: Gender Inequality Amongst U.S. Cabinet Departments, 1962-2011; 2012 Kentucky Political Science Association (2012)

- The Budget Gap: Gender Inequality Amongst U.S. Cabinet Departments, 1962-2010; 2011 Northeastern Political Science Association Conference (2011) 
- Gender and Budgets; 2011 University of Louisville SGA Graduate Student Symposium (2011)

- Get Out the Vote Presentation, Delaware, Ohio, Election Day and Early Voting Procedures (2008)

- Presentation to the City Manager of Delaware, Ohio, on the development of a bike-path maintenance program (2008)

\section{Political/Campaign Experience}

- Campaign Consultant to the Big Walnut Township Library Levy Committee (2009)

- Obama for America Election Day Volunteer Coordinator, Delaware City \& Northern Delaware County (2008)

- Obama for America Neighborhood Team Leader, Delaware City \& Northern Delaware County (2008)

- David Robinson for Congress Campaign Committee (2008)

- Ohio for Obama Primary GOTV (2008)

- Intern, City Manager of Delaware, Ohio (2008)

- Delaware, Ohio Democratic Party GOTV (2006)

- Kerry/Edwards Delaware County Campaign Committee (2004)

\section{Other Employment}

- Graduate Assistant, University of Louisville Political Science Department (2010-2012)

- Lifeguard, Champion Farms Apartment Complex (2010-2011)

- Delaware Ohio Racing Club Swim Coach (2007-2010)

- Delaware Aquatic Racing Team Swim Coach (2009)

- Lifeguard, Ohio Wesleyan University (2008-2009)

- Swim Coach, West Point Swim Camp $(2010,2008)$

- Lifeguard, City of Dublin (2003-2006)

\section{Extra-Curricular Achievement}

- Graduate Student Union, University of Louisville (2011-2012)

- Graduate Student Council, University of Louisville (2011-2012)

- Exec Board, OWU College Democrats/P.L.A.I.D. (2009-2010)

- President, International Studies Program Board (2009-2010)

- Treasurer, Ohio Wesleyan Model United Nations Club (2009-2010)

- President, Treasurer, Ohio Wesleyan Triathlon Club (2008-2010)

- Wesleyan Council on Student Affairs (2009-2010)

- Secretary, Ohio Wesleyan Mortarboard (2009-2010)

- Student-Faculty Committee on Intercollegiate Athletics (2008-2010)

- Ohio Wesleyan Representative, NCAA Student-Athlete Development Conference (Florida, 2009)

- Varsity Male Swimming Student-Athlete (2006-2010)

\section{Honors/Awards/Professional Societies}

- Graduate Student Union Research Award Recipient, 2011

- Pi Sigma Alpha, Upsilon Chapter

- Sigma Iota Rho

- Ohio Wesleyan Mortar Board Association

- James J. Hearn Award for Community Service, 2009

- Ohio Wesleyan University Top 10 Student-Athlete, 2009 
- Ohio Wesleyan University Dean's List (2006-2010)

- Ohio Wesleyan University Trustee's Scholarship Award (2006-2010)

- National High School Athletic Association All-American (2006)

- National High School Athletic Association Academic All-American (2006)

\section{$\underline{\text { Skills Set }}$}

- Two-course statistical analysis sequence, University of Louisville

- Sound research and research-writing skills

- Working knowledge common-use software including Microsoft Office Products, SPSS, Adobe, etc.

- Familiarity with GIS, Data-Ferret analysis programs, Lexis-Nexis and other online research and data-retrieval programs

- Thorough experience with Delaware County Democratic Party, establishing and maintaining campaign volunteer protocols and county-wide election management

- Strong experience in providing presentation, other materials to local governing institutions

- Extensive teaching, coaching, and youth recreational program development

- Extensive experience in speaking with local print and live media

\section{Hobbies}

- Athletic: Swimming, Triathlons, Cycling, Golf, Soccer, Racquetball, Ice Skating, Kayaking, Canoeing, open-water swimming

- Academic/Leisure: Model UN, Chess, Board, Card, \& Video games 